\title{
Model Test and Numerical Analysis on the Deformation and Stability of a Landslide Subjected to Reservoir Filling
}

\author{
Xinli Hu, Chuncan He (D, Chang Zhou, Chu Xu, Han Zhang, Qiang Wang, \\ and Shuangshuang Wu
}

Faculty of Engineering, China University of Geosciences, Wuhan, Hubei 430074, China

Correspondence should be addressed to Chuncan He; hechuncan@cug.edu.cn

Received 20 March 2019; Accepted 20 June 2019; Published 15 July 2019

Academic Editor: Stefano Lo Russo

Copyright ( 2019 Xinli Hu et al. This is an open access article distributed under the Creative Commons Attribution License, which permits unrestricted use, distribution, and reproduction in any medium, provided the original work is properly cited.

\begin{abstract}
Reservoir filling can affect the landslide stability and cause the landslide deformation within the reservoir area. In this paper, a physical model test and a series of numerical analyses were combined to investigate the landslide deformation and stability under reservoir filling. The surface deformation, deep displacement, and pore water pressure were recorded during the physical model test. In the model test, the increasing period of the pore water pressure inside the landslide is proposed to be a critical period for the landslide subjected to the reservoir filling. During this period, large landslide deformation occurred. The numerical analyses show that a greater factor of safety (FOS) appeared under a higher water level rising rate or a lower permeability coefficient during the water level rising stage when other variables are fixed, due to the domination of the reservoir buttressing effect which can increase the landslide resistance. During the reservoir maintaining stage, the reservoir water infiltrated into the landslide continuously to cause the matric suction dissipation and pore water pressure increase, which reduced the landslide shear strength and then decreased the landslide stability.
\end{abstract}

\section{Introduction}

The Three Gorges Dam is the largest hydropower project in the world. The reservoir impoundment affects the landslide stability within the reservoir area, and more than 5300 landslides have been identified in the Three Gorges Reservoir area $[1,2]$. The drawdown of reservoir water is a critical condition for destabilizing landslides [3]. Observations that landslide deformation is associated with the reservoir drawdown have been widely reported [4-8]. The dynamic seepage pressure pointing outwards the slope is a crucial factor for deforming landslides after water level drawdown [9-11], especially when the landslide material has a low hydraulic conductivity [12]. Landslides were often found to show a retrogressive failure characteristic under drawdown conditions [10, 13-15]. The reservoir filling can also trigger or reactivate landslides. For example, the Qianjiangping landslide in the Three Gorges Reservoir area occurred shortly after the water level reached $135 \mathrm{~m}$, which claimed 24 lives and made 1200 people homeless [16]. Jones [17] observed landslides from 1941 to 1953 in the area around Roosevelt Lake in northeast Washington State, USA. It was found that $49 \%$ of the landslides occurred during the reservoir filling stage. Riemer [18] examined 60 publications regarding landslides in reservoir areas and found that $85 \%$ of landslides were induced during the reservoir filling or 2 years after the filling.

The field survey and monitoring, physical model tests, and numerical simulation tests are three effective methods to investigate the deformation and stability of landslides influenced by the reservoir impoundment [19-22]. Comparatively, the field survey and monitoring are more accurate than the other two methods. However, considerable amount of labor, material resources, and time are needed to install the monitoring equipment and collect data in the field monitoring [23]. Less labor and expense are required in the numerical simulation or physical model tests than in the field monitoring. Moreover, different test conditions and landslide geometries can be implemented for comparative analyses both in 


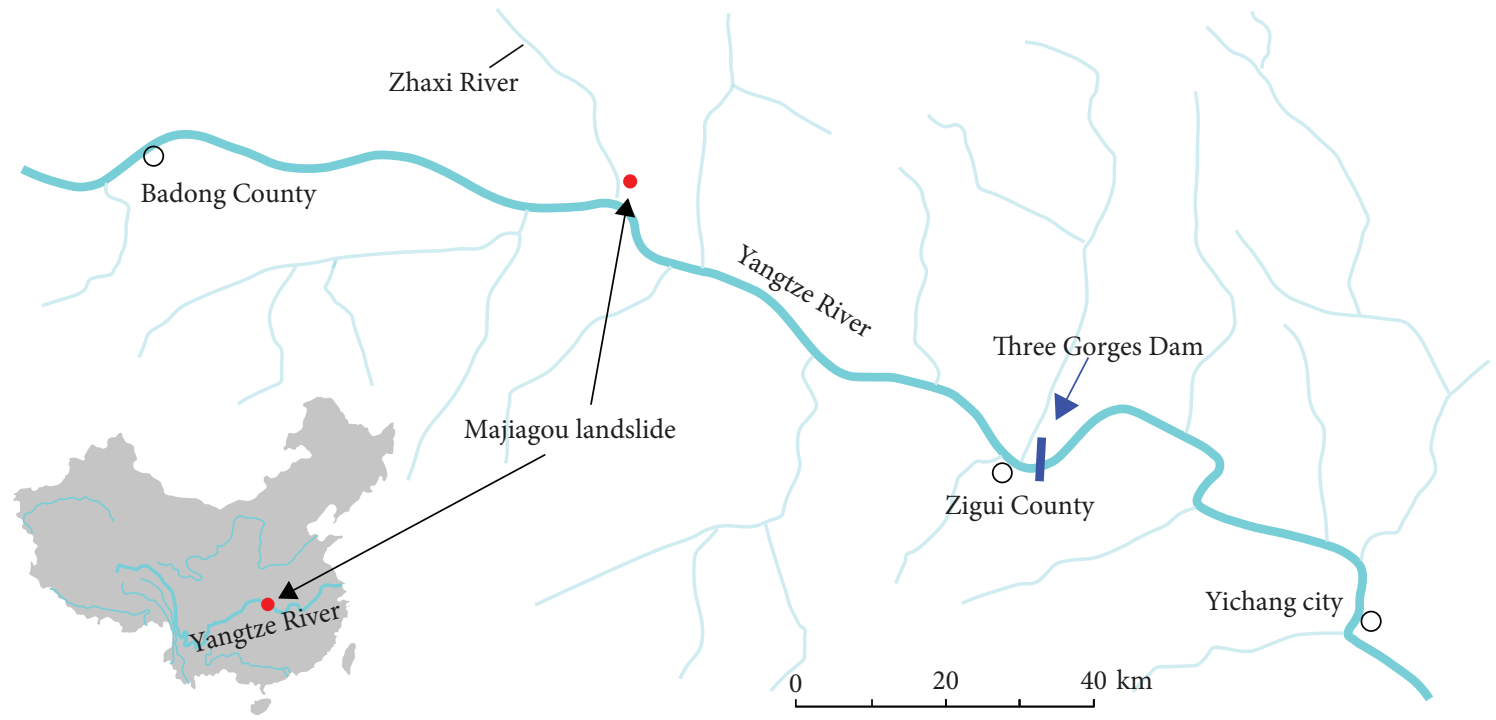

FIGURE 1: Location of the Majiagou landslide.

the numerical simulation and physical model tests [24-26]. Luo and Zhang [26] indicated that the slip surface became deeper inside the slope as the slope gradient increases under drawdown conditions using model tests.

However, there are still very few studies related to landslide stability and deformation under reservoir filling conditions [27], and few researches have analyzed the relation between the seepage field and landslide deformation during the reservoir filling. The mechanism for the landslide stability variation and deformation under reservoir filling also needs exploration. The accuracy of the landslide deformation analysis can be enhanced when considering the landslide deep displacement. The existing studies conducted with model tests mainly focused on the investigation of landslide surface displacement $[13,28-30]$, and the analysis involving the landslide deep displacement in model tests is rare.

In this paper, the physical model test and numerical simulation were combined to study the deformation and stability of a landslide subjected to the reservoir filling. The landslide surface and deep displacement are analyzed in the model test. The correlation between the landslide deformation and the pore water pressure is examined using the grey relational analysis. In the numerical tests, the effect of hydraulic conductivity and water level rising rate on the landslide stability is studied, and the mechanism for the landslide stability variation under reservoir filing is also discussed. The results provide improved insight into the deformation and stability of a landslide subjected to the reservoir filling.

\section{Geology of the Majiagou Landslide}

The Majiagou landslide was selected as an example to develop the physical and numerical landslide model. The landslide is located on the left bank of the Zhaxi River in the Three Gorges Reservoir (Figure 1). The landslide moved after the reservoir was first impounded in 2003. The toe of this landslide is $135 \mathrm{~m}$ above the sea level, and the crown is at an elevation of $280 \mathrm{~m}$. The average slope of the Majiagou landslide is $15^{\circ}$, and the sliding direction is almost perpendicular to the Zhaxi River [31] (Figure 2).

Surficial deposits and sedimentary bedrock are the main material of the Majiagou landslide based on the field investigation. The surficial deposit is composed of gravel mixed with silty clay. The bedrock consists of weathered interbedded gray sandstone and purple-red mudstone of the Jurassic Suining Formation (Figure 3). The purple-red mudstone can be softened by water and has low strength, which causes the silty mudstone beneath the surficial deposits to weather and become the sliding zone eventually $[2,31]$.

\section{Physical Model Test}

\subsection{Landslide Model}

3.1.1. Model Geometry. The physical model is comprised of a model frame, a landslide model, and a monitoring system as shown in Figure 4. A testing frame with a length of $2.8 \mathrm{~m}$, a width of $1.1 \mathrm{~m}$, and a height of $1.5 \mathrm{~m}$ was used in the test. The interior of the model frame is waterproof. The front and one side of the frame were made of transparent tempered glass for observing the water level and landslide deformation inside the frame. The other side and back of the frame were made of steel.

3.1.2. Landslide Materials. The landslide model consists of a sliding mass, sliding zone, and bedrock. The landslide model is $2.7 \mathrm{~m}$ long and $1 \mathrm{~m}$ wide. The sliding mass and sliding zone have an average thickness of $0.32 \mathrm{~m}$ and $40 \mathrm{~mm}$, respectively (Figure 4).

The material properties used for constructing the landslide model were determined by the law of similitude [32]. The landslide model was required to be similar to the prototype in terms of the geometry, material properties, and boundary conditions. The ratio of the prototype to model in the certain parameters (e.g., length, density, and cohesion) is defined as the similar ratio. The parameters between the 


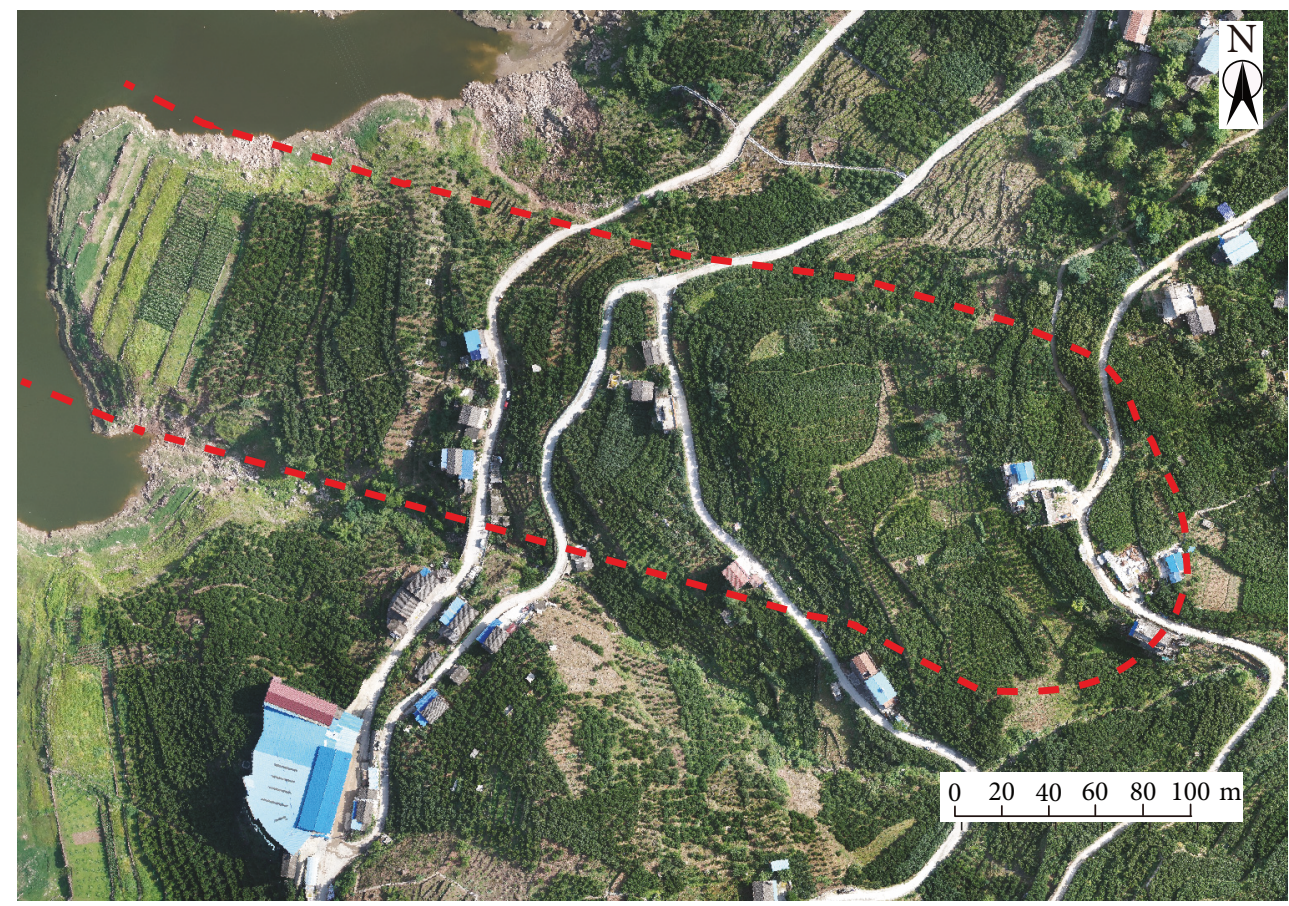

Figure 2: Boundary of the Majiagou landslide (plan view).

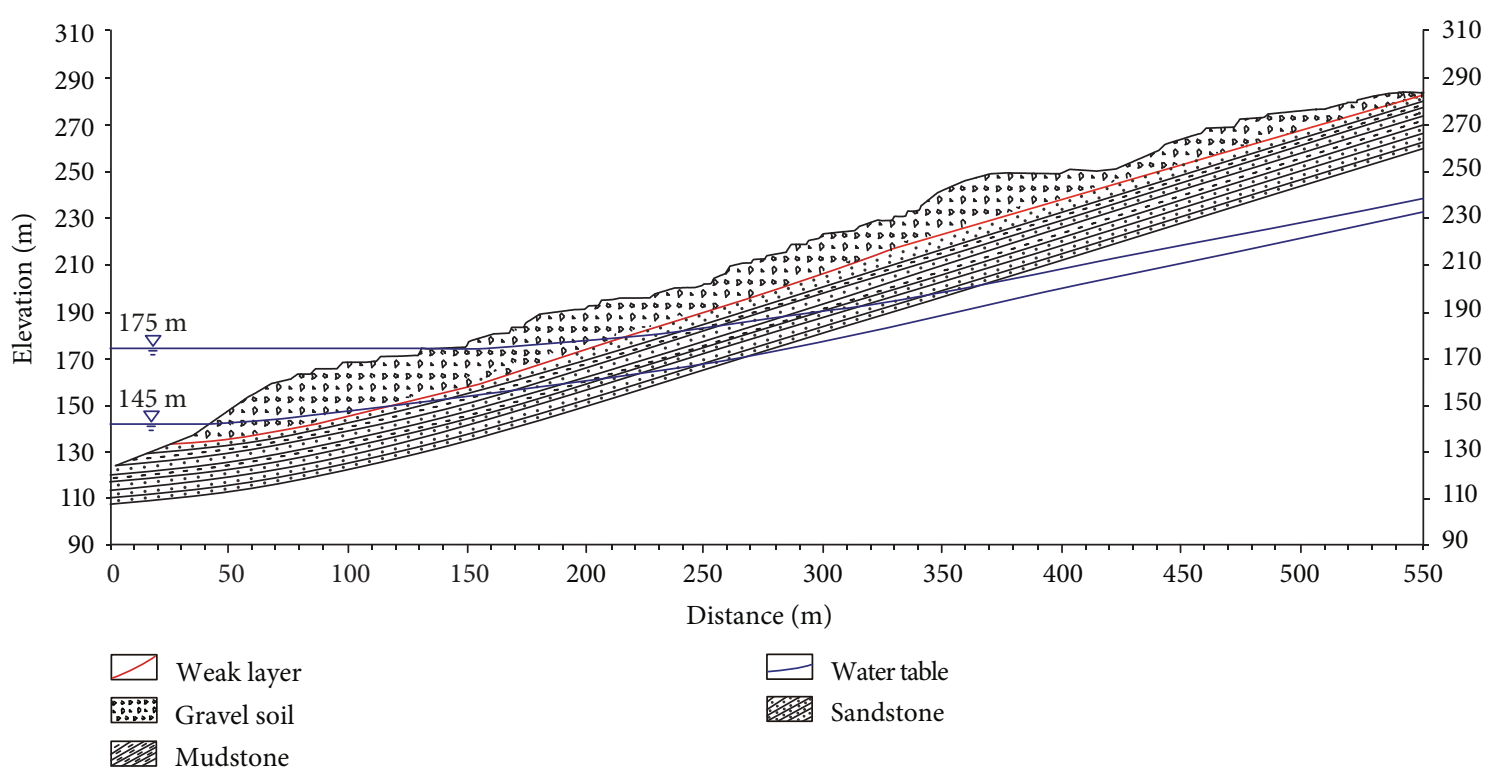

Figure 3: Vertical profile along the Majiagou landslide.

Majiagou landslide and the physical model were converted based on the Buckingham $\pi$ theorem [33]. The similar ratio of gravity and density was set as $C_{g}=1$ and $C_{\rho}=1$, respectively, and the similar ratio of geometry was set as $C_{l}=n=40$ in this study. The similar ratio of other parameters was derived using the dimensional method. The results are shown in Table 1.

The bedrock of the landslide model was constructed with masonry and cement mortar. The sliding mass was made from a mixture of sand, clay, water, and bentonite with a ratio of
$28.5: 62.5: 8: 1$, and the sliding zone was composed of glass beads, clay, and water in proportions of $60: 32: 8$. These ratios were obtained after a series of repeated matching tests. The clay both used in the sliding mass and sliding zone was obtained from the Majiagou landslide. The material properties of the Majiagou landslide and the model are listed in Table 2.

The clay used in the tests was dried, crushed, and screened by a $2 \mathrm{~mm}$ mesh before the mixture of the materials. To obtain homogeneous and mixed materials, a concrete 


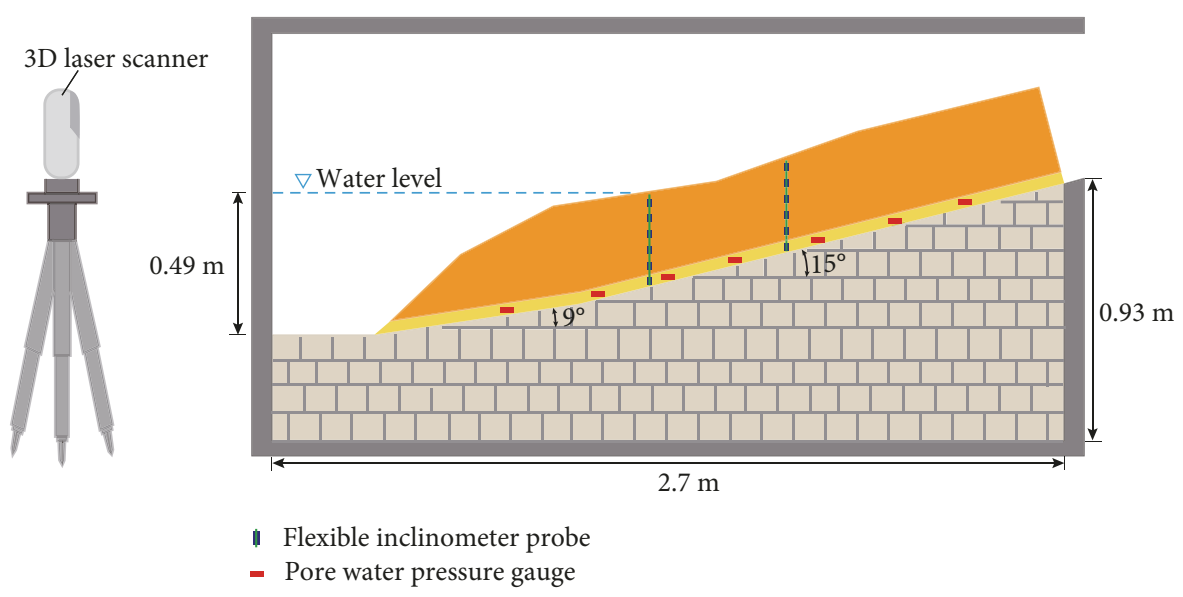

FIgURE 4: Layout of the physical model.

TABLE 1: Similar ratio of principal parameters $(n=40)$.

\begin{tabular}{lcccc}
\hline Items & Gravity $(g)$ & Length $(L)$ & Density $(\rho)$ & Elastic modulus $(E)$ \\
\hline Similar ratio & 1 & $n$ & 1 & $n$ \\
Items & Cohesion $(c)$ & Friction angle $(\varphi)$ & Permeability coefficient $(K)$ & $n^{1 / 2}$ \\
Similar ratio & $n$ & 1 & & \\
\hline
\end{tabular}

TABle 2: Material parameters of the Majiagou landslide and model.

\begin{tabular}{lcccccc}
\hline Object & & Density $\left(\mathrm{kg} / \mathrm{m}^{3}\right)$ & Cohesion $(\mathrm{kPa})$ & Friction angle $\left(^{\circ}\right)$ & Elastic modulus $(\mathrm{MPa})$ & $\begin{array}{c}\text { Permeability coefficient } \\
(\mathrm{m} / \mathrm{s})\end{array}$ \\
\hline \multirow{2}{*}{ Majiagou landslide } & Sliding mass & 21.14 & N/A & N/A & 300 & $2 \times 10^{-6}$ \\
& Sliding zone & 21.14 & $16-18$ & $17-19$ & 100 & $1.5 \times 10^{-6}$ \\
\hline \multirow{2}{*}{ Model } & Sliding mass & 22.1 & 3.9 & 23.8 & 2.4 & $4.52 \times 10^{-5}$ \\
& Sliding zone & 17.1 & 5.6 & 18.1 & 2.2 & $2 \times 10^{-7}$ \\
\hline
\end{tabular}

mixer was employed during the mixing process and the mixing time was set at $20 \mathrm{~min}$ each time. In the construction of the landslide model, the layered construction and compaction were applied. The sliding zone was constructed in a $40 \mathrm{~mm}$ layer. The sliding mass was constructed in $50 \mathrm{~mm}$ thick layers. Each layer was compacted by hand tamping 160 times with a rubber hammer. The landslide model was hand trimmed to obtain the designed shape before finishing the construction.

To simulate the landslide subjected to the reservoir filling, the reservoir water level was gradually raised from $0.4 \mathrm{~m}$ (the landslide toe) to an elevation of $0.89 \mathrm{~m}$ over $30 \mathrm{~min}$ and maintained at that elevation for $120 \mathrm{~min}$.

3.2. Monitoring. A RIEGL VZ-400 3D laser scanner was used to measure the surface deformation of the model (Figure 4). White spherical pushpins with a diameter of $8.5 \mathrm{~mm}$ were placed as surface monitoring points on the landslide model surface (Figure 5). The 3D laser scanner was set about
$0.5 \mathrm{~m}$ in front of the model frame, and it scanned the surface every $5 \mathrm{~min}$ to obtain point cloud data of the surface. The movement of the model surface was obtained after the surface monitoring point locations were further analyzed.

Seven pore water pressure gauges $(27 \mathrm{~mm}$ in diameter and $15 \mathrm{~mm}$ thick) were placed in the sliding zone along the center axis of the landslide model, as shown in Figures 4 and 5 .

Two flexible inclinometer probes $\mathrm{C} 1$ and $\mathrm{C} 2$ were set in a vertical orientation, perpendicular to the center axis of the model to monitor the landslide deep displacement (Figures 4 and 5). The measurement device for the deep displacement monitoring includes a flexible probe, controller, and PC software (Figure 6). The measurement principle of the probe and its verification in physical model tests were presented by Zhang et al. [34]. The flexible probe contains the gravitational acceleration measurement units (Figures 5 and 6). The horizontal displacement of each measurement unit in the probe was obtained based on 


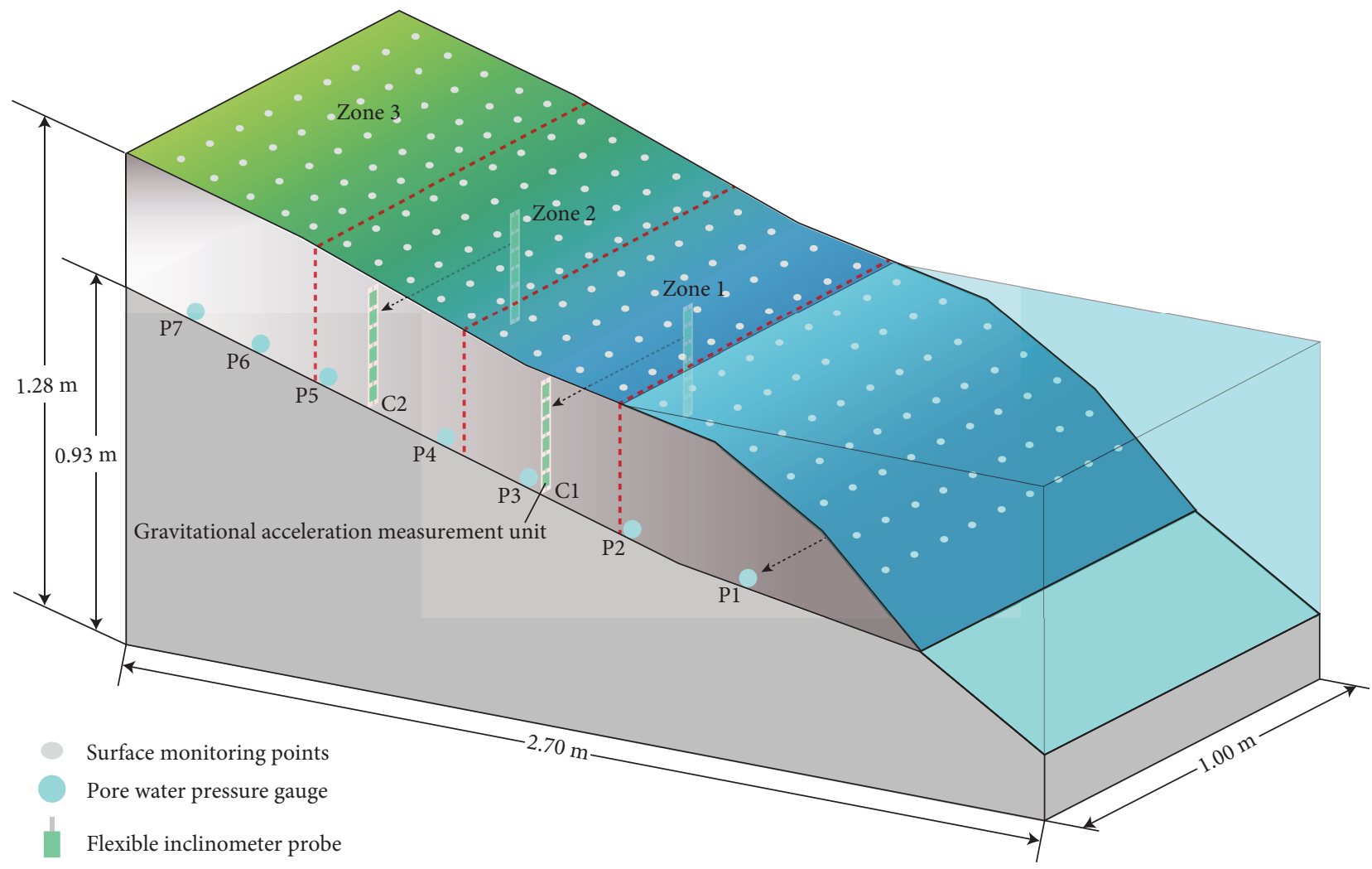

FIgURE 5: Monitoring in the model test.

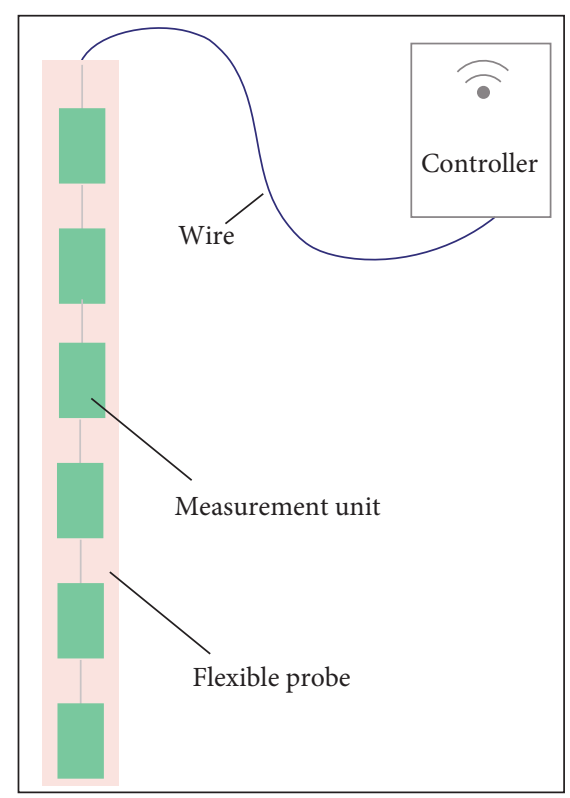

FIGURE 6: Components of the deep displacement measurement device.

the angle measurement using the gravitational acceleration measurement units. The collected displacement data were sent to the computer by the controller through the wireless communication [34].

\subsection{Results of the Model Test}

3.3.1. Pore Water Pressure. Figure 7 shows the variation of the pore water pressure and water level versus time in the model test. Lagged responses at all pore water pressure gauges are observed compared with the water level. The pore water pressure of $\mathrm{P} 1$ responds earliest and increases $13 \mathrm{~min}$ after the water level has risen. P2 has the largest value of pore water pressure $(2.92 \mathrm{kPa})$. The gauge of $\mathrm{P} 7$ has no change through the whole test which indicates the water does not reach the elevation of $\mathrm{P} 7$. The pore water pressure at $\mathrm{P} 1$, which has the lowest elevation among the seven gauges, does not rise as expected to exceed the value of $\mathrm{P} 2$. The rising rate of P1 decline after $20 \mathrm{~min}$, which is likely due to gauge failure. After $65 \mathrm{~min}$, the pore water pressures at all gauges become stable and keep almost constant until the test end.

3.3.2. Surface Displacement. The 3D laser scanner cannot capture the landslide surface movement under the water during the test. To better describe the feature of surface deformation, the landslide surface above the water is divided into three zones (Figure 5). The average displacements of monitoring points in the three zones versus time are shown in Figure 8. Zone 1, zone 2, and zone 3 start to deform $20 \mathrm{~min}, 31 \mathrm{~min}$ and $35 \mathrm{~min}$ after the water rises, respectively. Zone 1 which is closest to the reservoir has the largest average displacement $(11 \mathrm{~mm})$, and the deformation of zone 3 is the smallest $(1 \mathrm{~mm})$. The displacement rates of these three zones become smaller after $65 \mathrm{~min}$. 


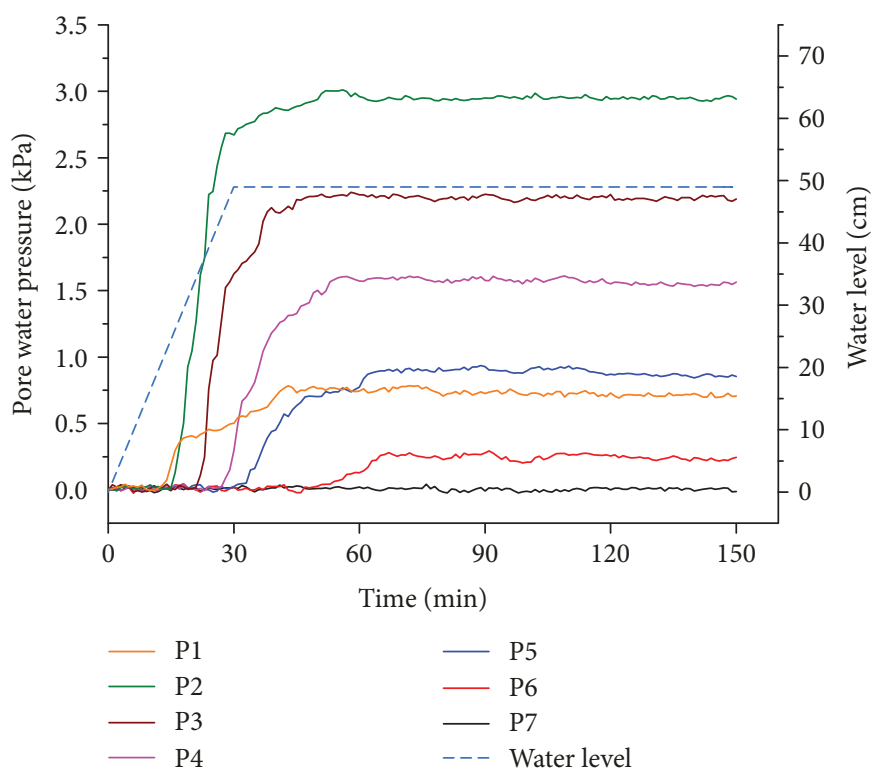

FIGURE 7: Water level and pore water pressure versus time in the model test.

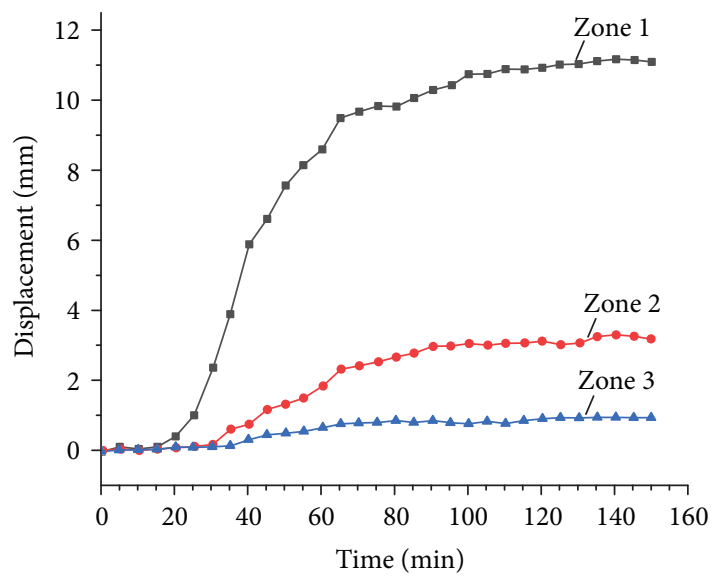

FIGURE 8: Average displacements of monitoring points in the three zones versus time.

3.3.3. Deep Displacement. Figure 9 presents the variation of the deep displacement in the flexible inclinometer probes $\mathrm{C} 1$ and $\mathrm{C} 2$. The displacement of $\mathrm{C} 1$ (located in zone 1) increases obviously during 15 to $60 \mathrm{~min}$, which is almost consistent with the surface displacement increase of zone 1. C2 has less total displacement compared with C1. Similar to $\mathrm{C} 1$, the rapid increase period (30 60 $\mathrm{min})$ of the displacement in C2 (located in zone 2) is also in accord with the surface displacement increase of zone 2. Both in C1 and C2, the deformation at the deeper section $(140 \mathrm{~mm} 300 \mathrm{~mm})$ is a bit larger than that at the shallow section $(0 \sim 140 \mathrm{~mm})$ after $15 \mathrm{~min}$ and $30 \mathrm{~min}$, respectively. The reason may be that the sliding zone containing the glass beads has smaller shear strength than the sliding mass under the softening effect of reservoir water. Then, the deeper soil which is closer to the sliding zone deforms greater than the soil in the shallow area.

3.3.4. Overall Deformation Distribution. Based on the deep and surface displacement, the overall deformation contour of the three zones can be obtained using the triangulation and linear interpolation $[35,36]$. The displacements of $\mathrm{C} 1$ and C2 (located in zone 1 and zone 2, respectively) can be used as the deep displacements of zone 1 and zone 2 in the contour plotting of the overall deformation. However, the deep displacement of zone 3 is unknown, as few surface deformations appeared in zone 3 (less than $1 \mathrm{~mm}$ ), and the surface displacement is close to the deep displacement according to zone 1 and zone 2. Therefore, the deep displacement was set to be the same with the surface displacement in the overall deformation contour plotting of zone 3 . The overall deformation contour of zone 1, zone 2 , and zone 3 and saturation lines at different times are shown in Figure 10.

The displacement beneath the water (grey portion in Figure 10) was not presented due to the limitation of the 3D laser scanner. From Figure 10(a), few deformations (less than $0.8 \mathrm{~mm}$ ) are found in zone 1 at $20 \mathrm{~min}$, and the deformation of zone 2 and zone 3 is almost $0 \mathrm{~mm}$. Then, the displacement of zone 1 increases to about $4 \mathrm{~mm}$ at $30 \mathrm{~min}$ when the water level reaches the highest elevation $(0.89 \mathrm{~m})$ (Figure $10(\mathrm{~b}))$. At $65 \mathrm{~min}$, the largest deformation (occurs in zone 1) rises to about $13 \mathrm{~mm}$ as the saturation line becomes almost parallel to the water level line. However, from $65 \mathrm{~min}$ to $150 \mathrm{~min}$, the saturation line almost keeps constant and few displacements (about $2 \mathrm{~mm}$ ) appear. The result shows that most landslide deformations occurred during the first $35 \mathrm{~min}(30 \sim 65 \mathrm{~min})$ of the water level maintaining stage. 


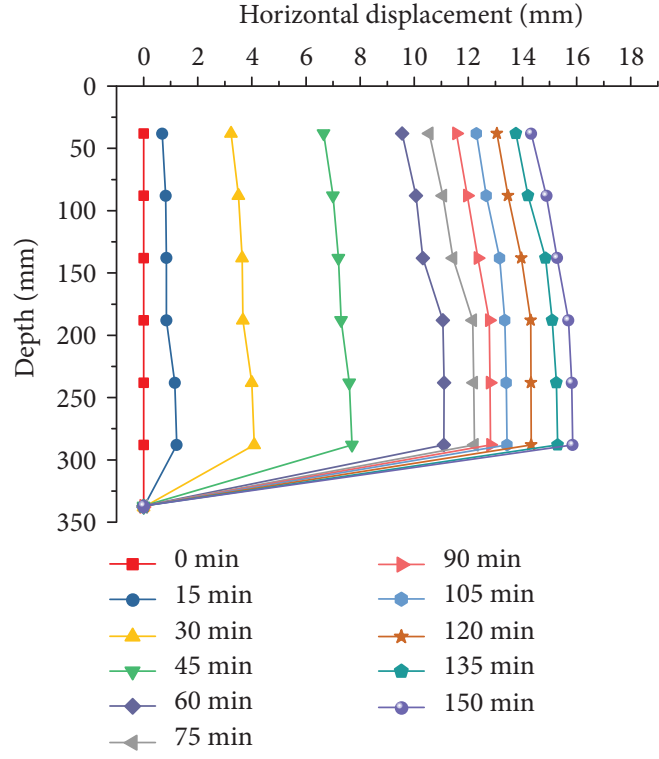

(a) $\mathrm{C} 1$

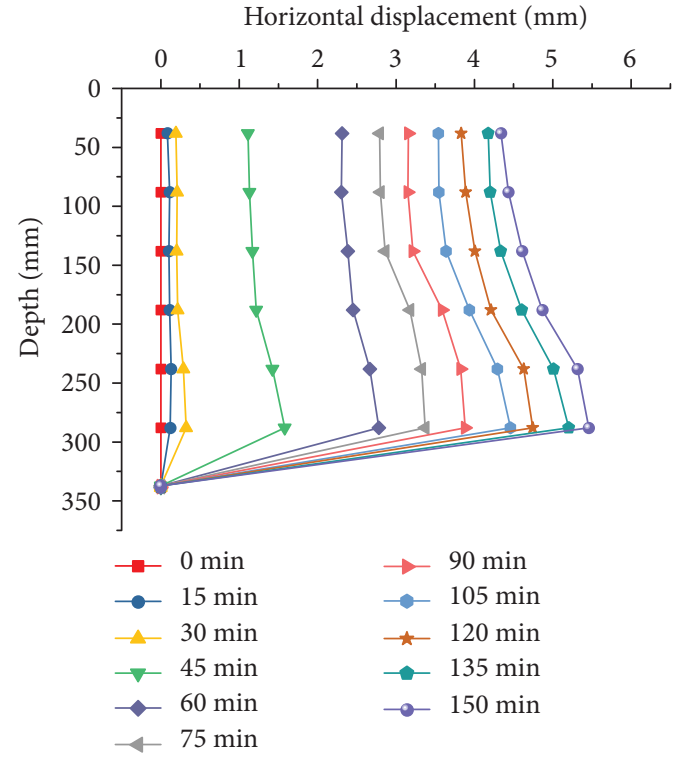

(b) $\mathrm{C} 2$

FIgURE 9: Variation of the deep displacement in flexible inclinometer probes of (a) $\mathrm{C} 1$ and (b) C2.

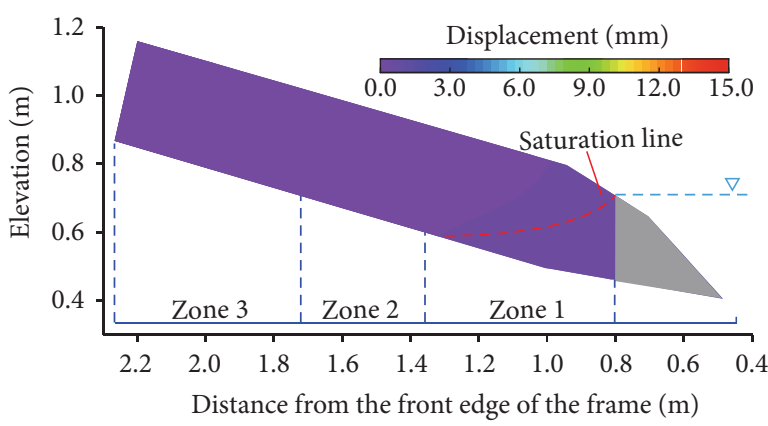

(a) $20 \mathrm{~min}$

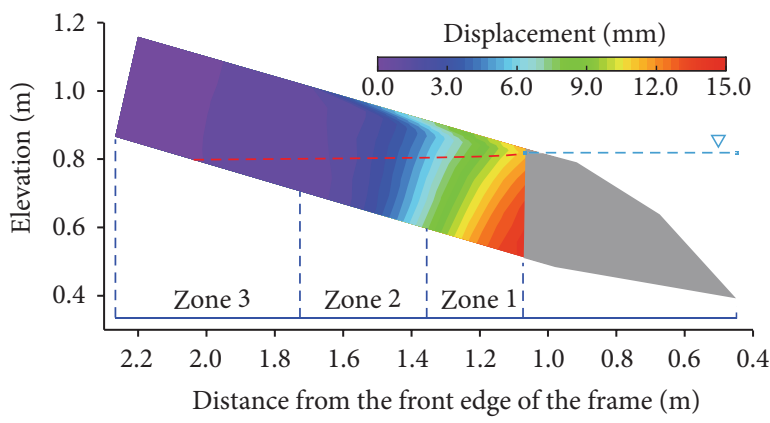

(c) $65 \mathrm{~min}$

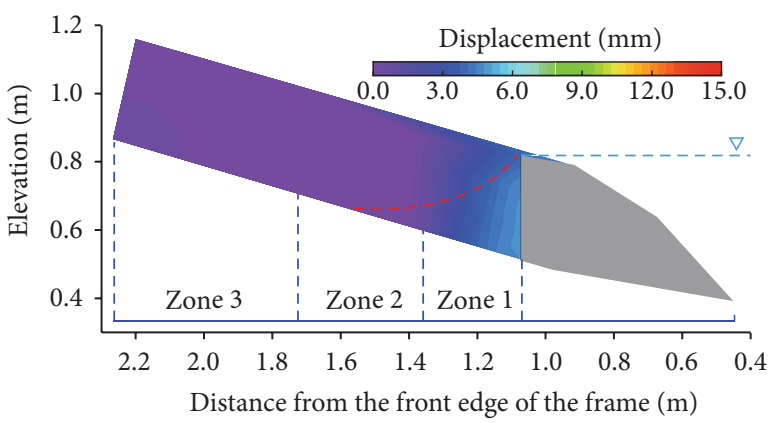

(b) $30 \mathrm{~min}$

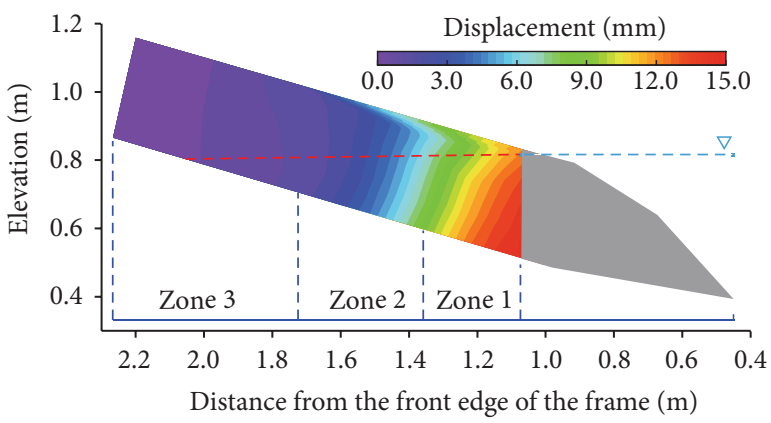

(d) $150 \mathrm{~min}$

Figure 10: Deformation of the three zones and saturation lines at different times.

\section{Numerical Tests}

4.1. Numerical Model. The seepage field of the landslide subjected to the first reservoir impoundment was simulated by the two-dimensional finite-element seepage module SEEP/W of the GeoStudio 2007 [37]. The Morgenstern-Price method is a vigorous limit equilibrium method of slices for slope stability calculation. It completely satisfies the equilibrium condition and involves the least numerical difficulties [38]. The factor of safety (FOS) of the Majiagou landslide was then calculated using the Morgenstern-Price method in the SLOPE/W module, which employed the transient seepage 


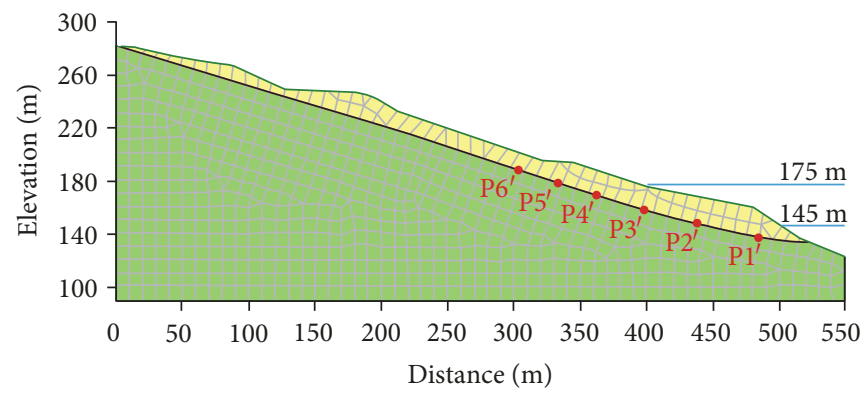

FIGURE 11: Numerical model of the Majiagou landslide.

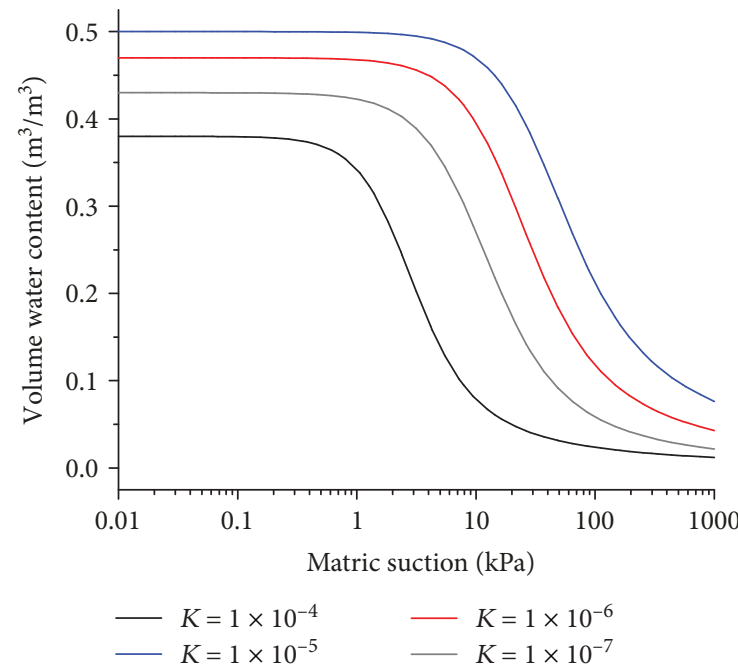

(a)

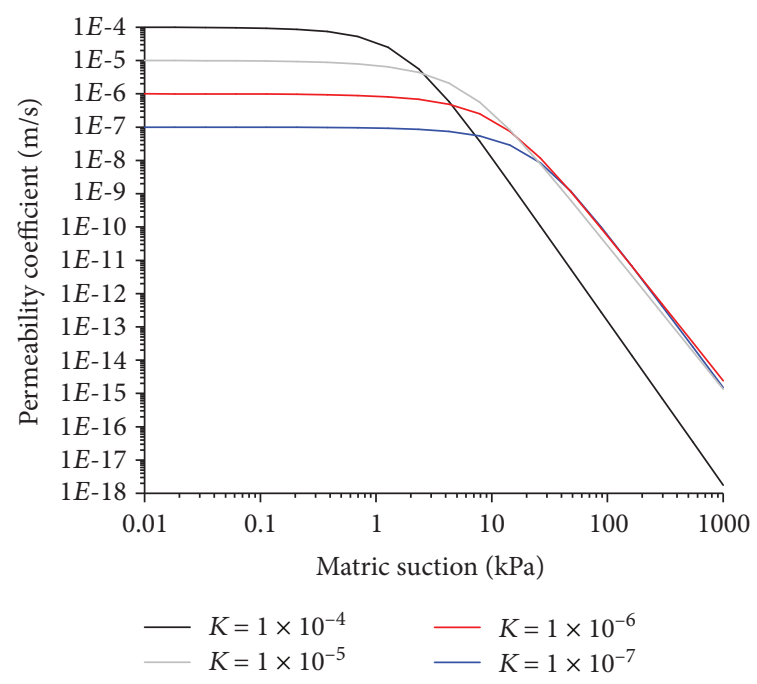

(b)

Figure 12: (a) Soil-water characteristic curves and (b) hydraulic conductivity functions of the sliding mass.

results obtained from SEEP/W. The vertical profile of the Majiagou landslide (Figure 3) was selected for establishing the numerical model.

The established finite-element model composed of the sliding mass, sliding surface, and bedrock is partitioned into 786 elements and 843 nodes (Figure 11). In the transient seepage analysis, the reservoir water is raised from $145 \mathrm{~m}$ to $175 \mathrm{~m}$ and then the water level is maintained at $175 \mathrm{~m}$. The boundary conditions of the model are set as follows: The boundary for the varying water head is at the front edge of the sliding mass from the elevation of $145 \mathrm{~m}$ to $175 \mathrm{~m}$. The groundwater level at the trailing edge of the landslide is set as the constant water head with an elevation of about $232 \mathrm{~m}$ based on the field groundwater monitoring data. The bottom line of the model is set as the impermeable boundary.

4.2. Test Scheme. To analyze the effect of the reservoir filling on the seepage field and stability of the landslide, four distinct permeability coefficients $\left(1 \times 10^{-4} \mathrm{~m} / \mathrm{s}, 1 \times 10^{-5} \mathrm{~m} / \mathrm{s}, 1 \times\right.$ $10^{-6} \mathrm{~m} / \mathrm{s}$, and $1 \times 10^{-7} \mathrm{~m} / \mathrm{s}$ ) for the sliding mass and seven different rising rates $(0.167 \mathrm{~m} /$ day, $0.2 \mathrm{~m} /$ day, $0.25 \mathrm{~m} /$ day, $0.33 \mathrm{~m} /$ day, $0.5 \mathrm{~m} /$ day, $1 \mathrm{~m} /$ day, and $2 \mathrm{~m} /$ day) were considered to conduct the comparative study. Before the transient seepage simulation, the steady-state seepage analysis was conducted to obtain the seepage field of the landslide under the water level of $145 \mathrm{~m}$. Then, the result was used as the initial condition for the transient seepage analysis under the reservoir impoundment (water level rising from $145 \mathrm{~m}$ to $175 \mathrm{~m}$ and maintaining at $175 \mathrm{~m}$ ).

The estimated soil-water characteristic curve and the hydraulic conductivity function of the sliding mass are shown in Figure 12. The hydraulic permeability functions of the sliding mass were evaluated using the Van Genuchten method [39]. The parameters for estimating the soil-water characteristic curve and the hydraulic conductivity function presented by Paronuzzi et al. [22] were applied in this study (Table 3). In the landslide stability evaluation, the parameters of the landslide material for the stability calculation are shown in Table 4.

\subsection{Results of the Numerical Simulation}

4.3.1. Transient Seepage Field. Figure 13 shows the saturation lines of the landslide under different permeability coefficients as the reservoir water rises from $145 \mathrm{~m}$ to $175 \mathrm{~m}$ over 90 days and is then maintained. From Figure 13, the permeability of the landslide material affects the transient seepage field inside the landslide. The saturation lines at the slope toe are flatter 
TABLe 3: Parameters related to the permeability of the landslide material.

\begin{tabular}{lccc}
\hline Unit & Saturated permeability $(\mathrm{m} / \mathrm{s})$ & Saturated water content $\left(\mathrm{m}^{3} / \mathrm{m}^{3}\right)$ & $\begin{array}{c}\text { Residual volume water } \\
\text { content }\left(\mathrm{m}^{3} / \mathrm{m}^{3}\right)\end{array}$ \\
\hline & $1 \times 10^{-4} \mathrm{~m} / \mathrm{s}$ & 0.38 & 0.02 \\
Sliding mass & $1 \times 10^{-5} \mathrm{~m} / \mathrm{s}$ & 0.43 & 0.03 \\
& $1 \times 10^{-6} \mathrm{~m} / \mathrm{s}$ & 0.47 & 0.06 \\
& $1 \times 10^{-7} \mathrm{~m} / \mathrm{s}$ & 0.50 & 0.13 \\
\hline Sliding zone & Same to the sliding mass & N/A & N/A \\
\hline Bedrock & $1 \times 10^{-11} \mathrm{~m} / \mathrm{s}$ & N/A & N/A \\
\hline
\end{tabular}

TABle 4: Parameters of the landslide material for the stability calculation.

\begin{tabular}{lccc}
\hline Unit & $\begin{array}{c}\text { Unit weight } \\
\left(\mathrm{kN} / \mathrm{m}^{3}\right)\end{array}$ & Cohesion $(\mathrm{kPa})$ & $\begin{array}{c}\text { Friction } \\
\text { angle }\left(^{\circ}\right)\end{array}$ \\
\hline Sliding mass & 21.14 & 22.8 & 26.9 \\
Sliding zone & 21.14 & 17 & 18 \\
Bedrock & 25.2 & 3000 & 35 \\
\hline
\end{tabular}

under greater permeability coefficients during the water level rising (Figures 13(a) and 13(b)), and the front part of the saturation lines tends to show a concave shape under a smaller permeability coefficient $\left(1 \times 10^{-6} \mathrm{~m} / \mathrm{s}\right.$ and $\left.1 \times 10^{-7} \mathrm{~m} / \mathrm{s}\right)$ (Figures 13(c) and 13(d)). The concave saturation lines indicate that the groundwater level lags behind the reservoir water level. During the water level maintaining stage, less time is needed for the groundwater equilibrium under a high permeability coefficient. For example, the groundwater almost follows the change of the reservoir water level under a permeability coefficient of $1 \times 10^{-4} \mathrm{~m} / \mathrm{s}$ (Figure $13(\mathrm{a})$ ). However, under a permeability coefficient of $1 \times 10^{-7} \mathrm{~m} / \mathrm{s}$, the groundwater cannot reach equilibrium though the reservoir is maintained for 3910 days (Figure 13(d)).

4.3.2. Stability of the Landslide. The FOS variation of the landslide during the water level rising and maintaining periods is presented in Figures 14 and 15. During the water level rising period, a greater FOS appears under a higher water level rising rate or a smaller permeability coefficient when other conditions are constant. In the water level maintaining stage, all FOSs decrease as the reservoir water infiltrates into the landslide and the FOSs drop to the same value under the same hydraulic conductivity. The FOS needs more time to decline to be stable under a smaller permeability coefficient due to a smaller water infiltration rate. From the deformation analysis in the physical model test, most landslide deformations occurred in the water level maintaining stage, which is consistent with the result here.

\section{Discussion}

5.1. Relation between Landslide Deformation and Seepage Field. The correlation between the landslide deformation and its impact factors (such as the reservoir fluctuation or rainfall) can be evaluated using the grey relational analysis [10]. The grey relational degree which ranges from 0 to 1 can be obtained by the grey relational analysis. The closer the grey relational degree to 1 , the higher the correlation between the landslide deformation and impact factors. In this study, the pore water pressure is the only impact factor in the relational analysis. To find the correlation between the landslide deformation and the pore water pressure, four steps are described as follows:

(1) Determination of Calculation Sequences. The landslide displacement rate is set as the primary sequence. The only one subsequence is the variation rate of pore water pressure. $X=\left[X_{0}, X_{1}\right]=[$ landslide displacement rate, variation rate of the pore water pressure]

(2) Normalization of the Value in Each Sequence. The data of each sequence are equalized using

$$
X_{i}(k)^{\prime}=\frac{X_{i}(k)}{(1 / n) \sum_{k=1}^{n} X_{i}(k)},
$$

where $i=0,1, \cdots, m ; k=1, \cdots, n ; m$, the number of influencing factors ( $m=1$ in this study); and $n$, the number of data points

(3) Calculation of Correlation Coefficients between Primary-Sequence $\left(X_{0}\right)$ and Subsequence $\left(X_{1}\right)$. The calculation method is shown as follows:

$$
\begin{aligned}
& \xi\left(X_{0}(k)^{\prime}, X_{i}(k)^{\prime}\right) \\
& =\frac{\min _{i} \min _{k}\left|X_{i}(k)^{\prime}-X_{0}(k)^{\prime}\right|+\rho \max _{i} \max _{k}\left|X_{i}(k)^{\prime}-X_{0}(k)^{\prime}\right|}{\left|X_{i}(k)^{\prime}-X_{0}(k)^{\prime}\right|+\rho \max _{i} \max _{k}\left|X_{i}(k)^{\prime}-X_{0}(k)^{\prime}\right|},
\end{aligned}
$$

where $\xi\left(X_{0}(k)^{\prime}, X_{i}(k)^{\prime}\right)$ is the correlation coefficients between sequences $X_{0}$ and sequences $X_{i}$ and $q$ is the resolution coefficient, which is set as 0.5 normally 


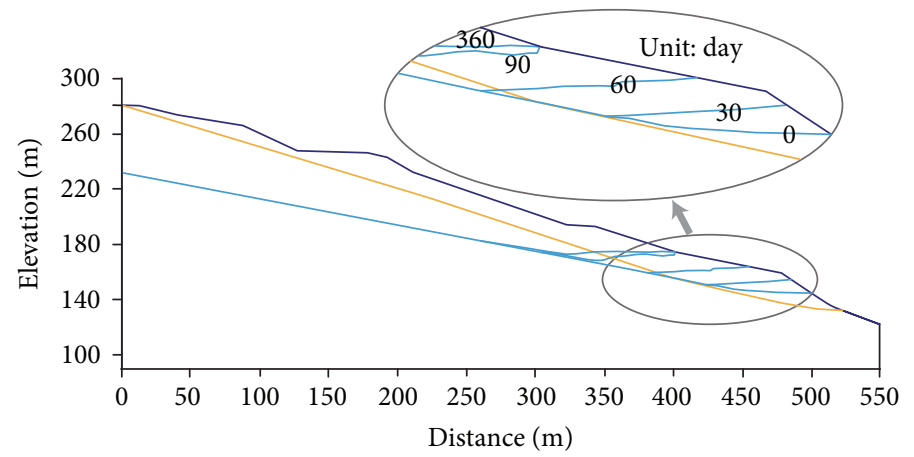

(a) $1 \times 10^{-4} \mathrm{~m} / \mathrm{s}$

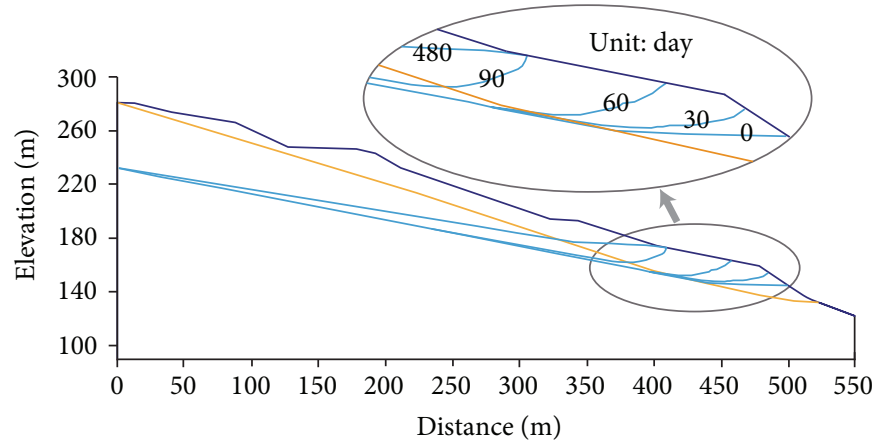

(b) $1 \times 10^{-5} \mathrm{~m} / \mathrm{s}$

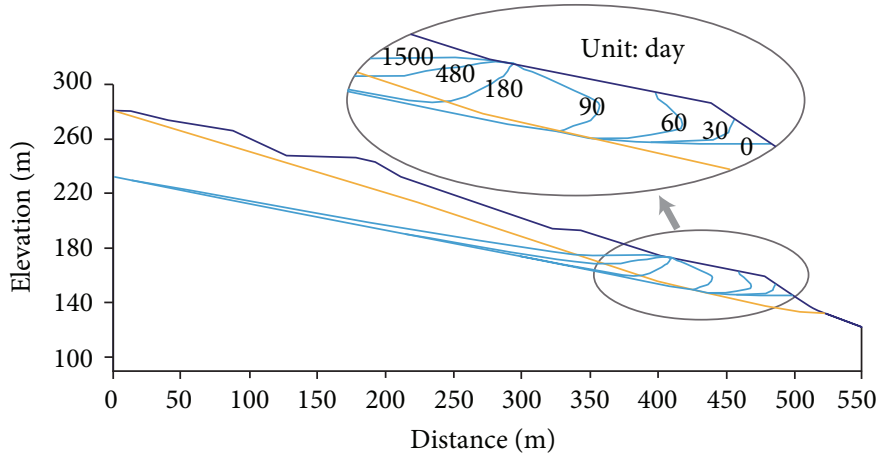

(c) $1 \times 10^{-6} \mathrm{~m} / \mathrm{s}$

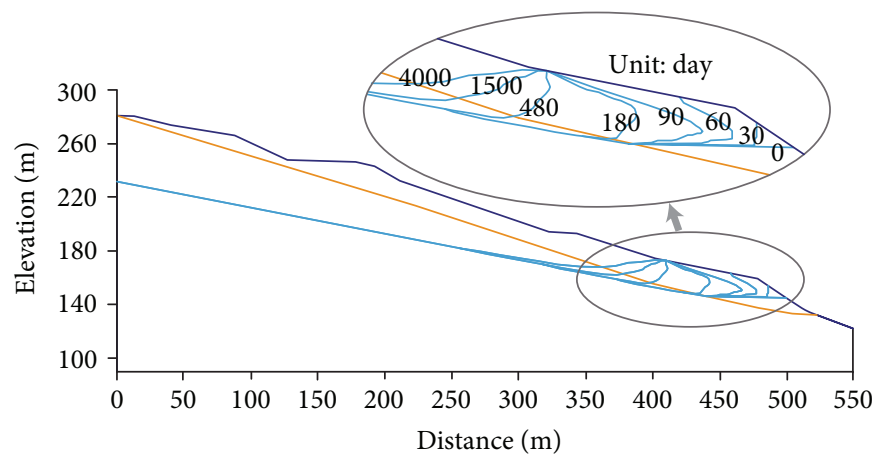

(d) $1 \times 10^{-7} \mathrm{~m} / \mathrm{s}$

FIGURE 13: Saturation lines during rising (from $145 \mathrm{~m}$ to $175 \mathrm{~m}$ in 90 days) and maintaining of the reservoir water. 


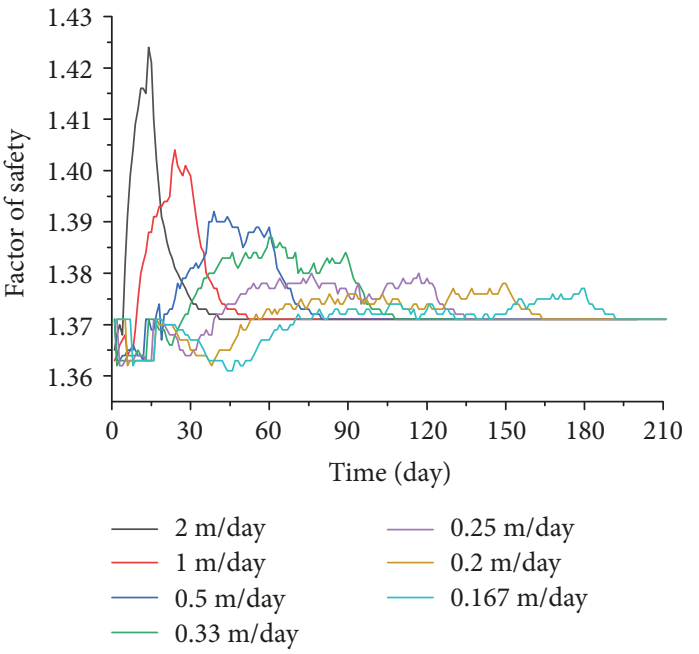

(a) $K=1 \times 10^{-4} \mathrm{~m} / \mathrm{s}$

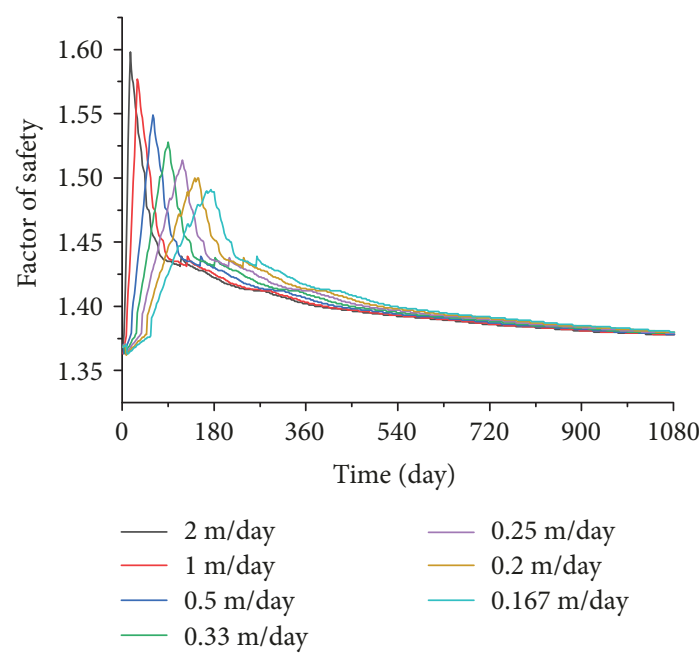

(c) $K=1 \times 10^{-6} \mathrm{~m} / \mathrm{s}$

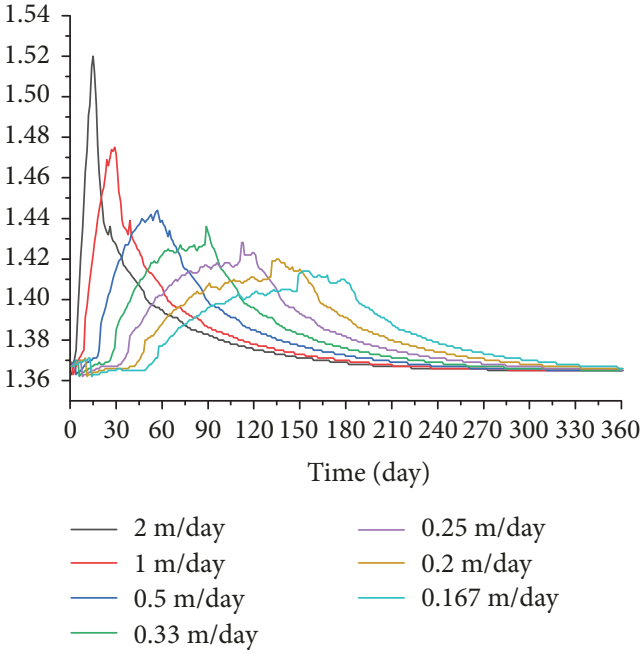

(b) $K=1 \times 10^{-5} \mathrm{~m} / \mathrm{s}$

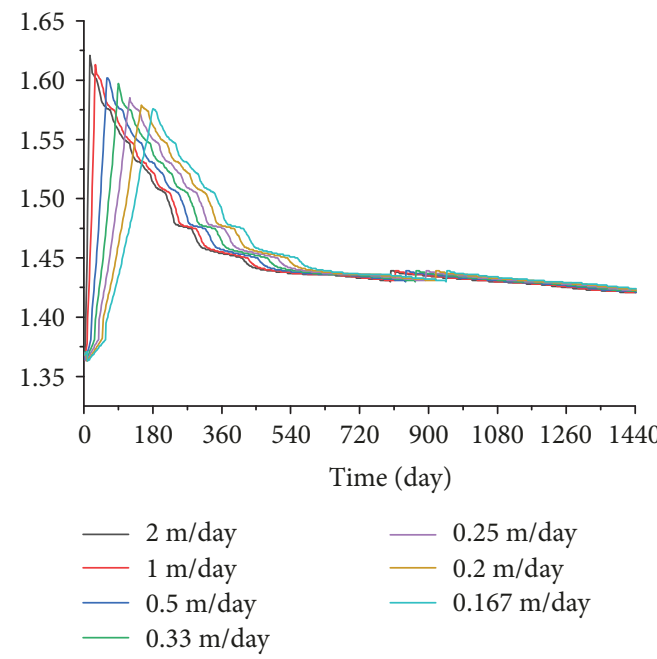

(d) $K=1 \times 10^{-7} \mathrm{~m} / \mathrm{s}$

FIGURE 14: FOS variation under different conditions.

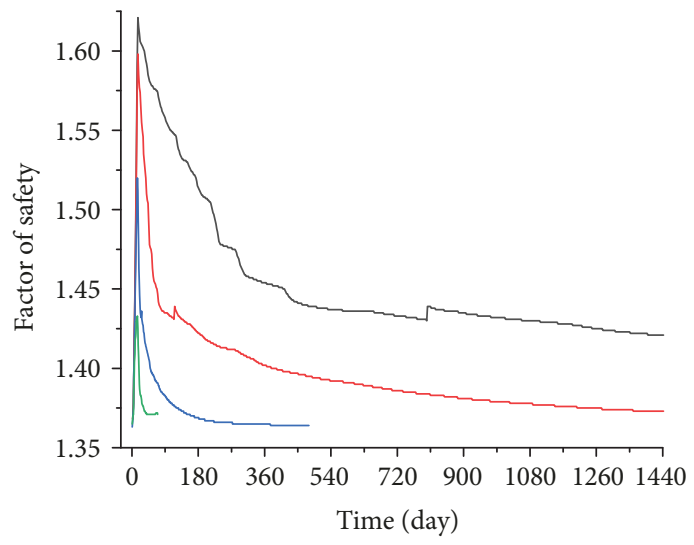

Water level rising rate $=2 \mathrm{~m} /$ day

$K=1 \times 10^{-4} \mathrm{~m} / \mathrm{s}-K=1 \times 10^{-6} \mathrm{~m} / \mathrm{s}$

$-K=1 \times 10^{-5} \mathrm{~m} / \mathrm{s}-K=1 \times 10^{-7} \mathrm{~m} / \mathrm{s}$

FIGURE 15: FOS variation under the water level rising rate of $2 \mathrm{~m} /$ day.
(4) Calculation of the Grey Relational Degree. The grey relational degree can be calculated from

$$
r\left(x_{0}, x_{i}\right)=\frac{1}{n} \sum_{k=1}^{n} \xi\left(x_{0}(k)^{\prime}, x_{i}(k)^{\prime}\right) .
$$

$\mathrm{P} 2, \mathrm{P} 4$, and $\mathrm{P} 5$ are located in the front part of zone 1, zone 2 , and zone 3, respectively. The pore water pressures of $\mathrm{P} 2$, P4, and P5 (Figure 7) are selected to conduct the grey relational analysis with the landslide surface deformation of zone 1, zone 2, and zone 3 (Figure 8), respectively. After the calculations, the grey relational degrees of the three pairs of analyses are $0.8,0.8$, and 0.7. The result indicates that the landslide surface deformation is related to the pore water pressure variation.

To further study the relation between the landslide deformation and the pore water pressure, the average displacement of the landslide surface (zone 1 to zone 3) 


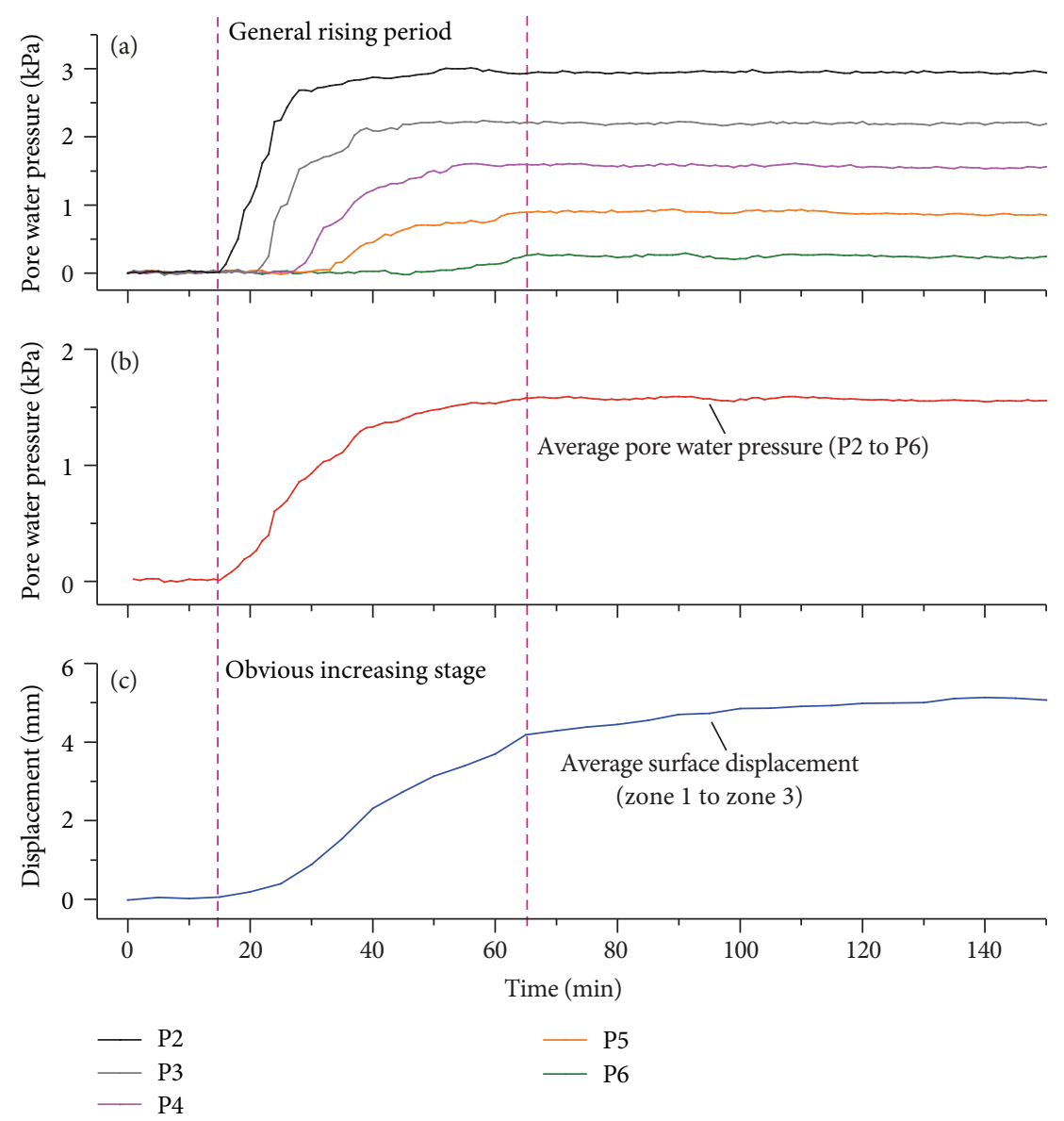

Figure 16: (a) Pore water pressure of P2 P6 and (b) their average value and (c) average surface displacement versus time.

was calculated and presented in Figure 16(c), which is compared with the pore water pressure variation of P2 to P6 (Figure 16(a)) and the average variation trend of these five pore water pressure curves (Figure 16(b)).

The grey relational degree between the average pore water pressure and the surface average displacement is 0.92 by the calculation. In addition, the main increasing stage (from $15 \mathrm{~min}$ to $65 \mathrm{~min}$ ) of the landslide surface displacement (Figure 16(c)) is consistent with the rising period of the pore water pressure (P2 to P6) (Figure 16(a)). It indicates that the deformation is closely related to the increase of the pore water pressure. The increasing period of the pore water pressure inside the landslide is proposed to be a critical period for the landslide subjected to the reservoir filling. During this critical period, large landslide deformation appears, especially in the area close to the reservoir (zone 1).

5.2. Mechanism for the Landslide Stability Variation. Shear strength of the unsaturated soil can be expressed as [40]

$$
\tau=\left[c^{\prime}+\left(\sigma_{n}-u_{a}\right) \tan \phi^{\prime}\right]+\left(u_{a}-u_{w}\right)\left[\left(\frac{\theta-\theta_{\mathrm{r}}}{\theta_{\mathrm{s}}-\theta_{\mathrm{r}}}\right) \tan \phi^{\prime}\right],
$$

where $\tau$ is the shear stress, $c^{\prime}$ is the effective cohesion, $\sigma_{\mathrm{n}}$ is the normal total stress, $u_{\mathrm{a}}$ is the pore air pressure, $\phi^{\prime}$ is the effective friction angle, $u_{\mathrm{w}}$ is the pore water pressure, $\left(u_{\mathrm{a}}-u_{\mathrm{w}}\right)$ is the matric suction of the soil on the plane of failure, $\theta$ is the volumetric water content, $\theta_{\mathrm{r}}$ is the residual volumetric water content, and $\theta_{\mathrm{s}}$ is the volumetric water content at a saturation of $100 \%$.

This equation is applied at the landslide stability calculation in the SLOPE/W module. The first part of equation (1) is the saturated shear strength when the pore air pressure $u_{\mathrm{a}}$ is equal to the pore water pressure $u_{\mathrm{w}}$ [40]. During the reservoir water infiltration, the matric suction dissipation and pore water pressure increase reduced the shear strength and then caused the deformation or reduced the FOS (Figures 10, 14, and 15). The buttressing effect of the reservoir can explain the increase of landslide stability during the water level rising [22]. The buttressing force caused by the reservoir impoundment acting on the landslide surface increased the landslide resistance and thus raised the FOS during the water level rising period (Figures 14 and 15).

5.3. Interpretation of the Landslide Stability Variation and Deformation. The monitoring points $\mathrm{P}^{\prime}{ }^{\prime} \sim 6^{\prime}$ were set in numerical models for recording the pore water pressure during the numerical tests (Figure 11). Figure 17 presents the 


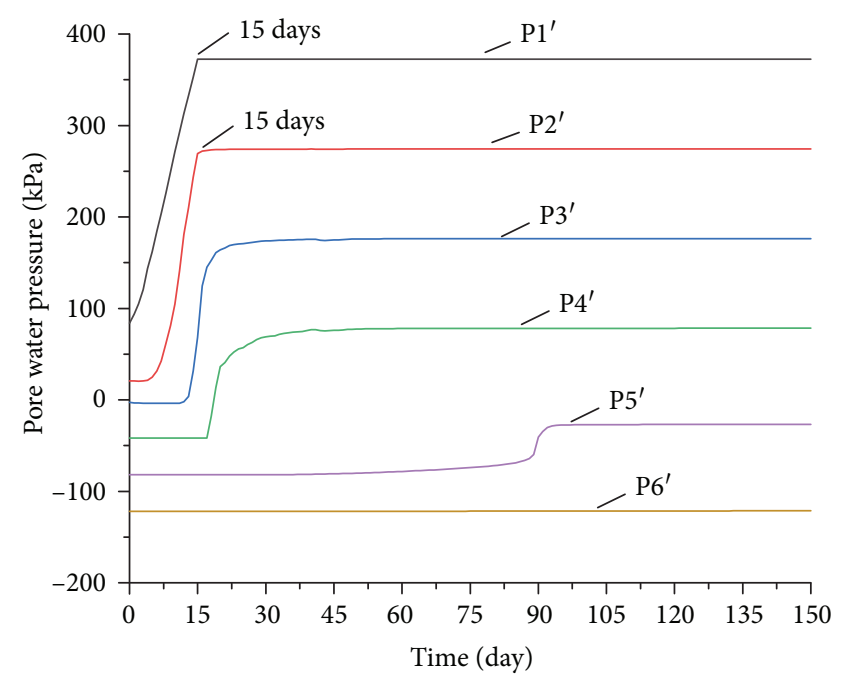

(a) $K=1 \times 10^{-4} \mathrm{~m} / \mathrm{s}$

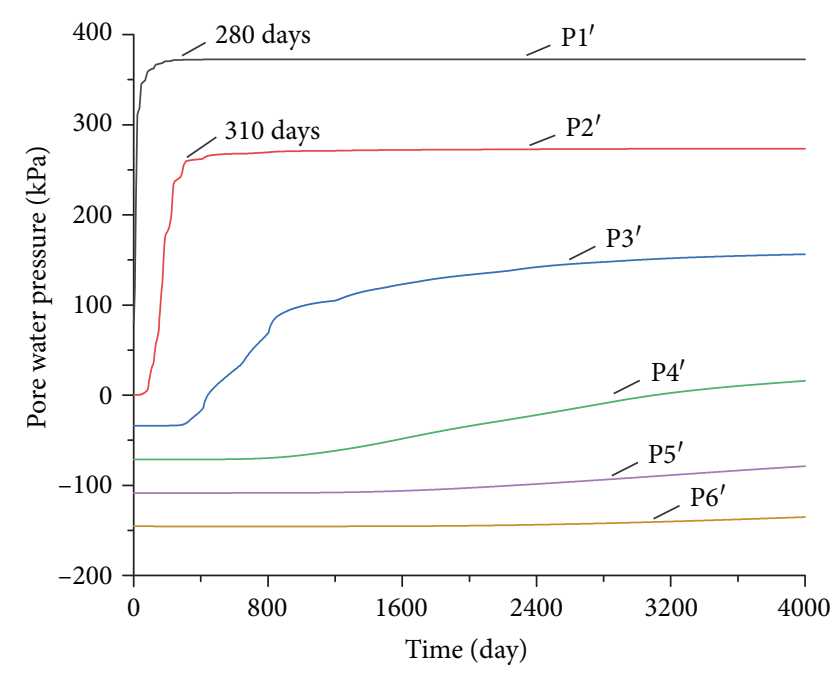

(b) $K=1 \times 10^{-7} \mathrm{~m} / \mathrm{s}$

Figure 17: Pore water pressure of $\mathrm{P}^{\prime} \sim \mathrm{P}^{\prime}$ versus time in numerical tests (water level rising rate $=2 \mathrm{~m} /$ day).

pore water pressure variation of $\mathrm{P}^{\prime} \sim \mathrm{P}^{\prime}$ under the water level rising rate of $2 \mathrm{~m} /$ day and permeability coefficients of $1 \times 10^{-4} \mathrm{~m} / \mathrm{s}$ and $1 \times 10^{-7} \mathrm{~m} / \mathrm{s}$. The evolution trend of the pore water pressure in numerical tests is similar to that of the model test in Figure 7. Both in the model and in the numerical tests, the pore water pressure in the landslide front part (P1, P2, P3, and $\mathrm{P}^{\prime}$ and $\left.\mathrm{P} 2{ }^{\prime}\right)$ increases quickly to the maximum value and then keeps constant and the pore water pressure in the rear part $\left(\mathrm{P} 6, \mathrm{P} 7\right.$, and $\mathrm{P} 5^{\prime}$ and $\left.\mathrm{P} 6^{\prime}\right)$ almost has the same variation characteristic (Figures 7 and 17). The pore water pressure of $\mathrm{P}^{\prime}$ and $\mathrm{P} 2^{\prime}$ under a higher permeability coefficient $\left(1 \times 10^{-4} \mathrm{~m} / \mathrm{s}\right)$ changes synchronously with the water level (Figure 17(a)). However, under a lower permeability coefficient $\left(1 \times 10^{-7} \mathrm{~m} / \mathrm{s}\right)$, the pore water pressure needs much more time to rise and get stable (Figure 17(b)).

Buttressing effect of the reservoir is the same in all numerical tests. A larger permeability coefficient or a slower water level rising rate allows more water to flow into the landslide, which is negative to the landslide stability during the reservoir filling. Therefore, under a greater permeability coefficient or a lower water level rising rate, a smaller FOS occurs in the reservoir filling stage (Figure 14). In the maintaining stage, the buttressing effect keeps constant but the reservoir water flows into the landslide continuously. Therefore, all FOSs decline due to the matric suction dissipation and pore water pressure increase. In the physical model test $\left(K>1 \times 10^{-4} \mathrm{~m} / \mathrm{s}\right)$, less deformation occurred in the water level rising stage and most deformation appeared during the early water level maintaining period. It agrees well with the numerical results and also can be explained by the reservoir buttressing effect and shear strength reduction caused by the reservoir water infiltration.

\section{Conclusions}

In this study, the physical model test and numerical tests were combined to study the deformation and stability of a landslide subjected to the reservoir filling. The Majiagou landslide in the Three Gorges Reservoir area was selected as an example to develop the physical and numerical models. During the physical model test, the surface deformation, deep displacement, and pore water pressure were recorded and the relationship between the landslide deformation and the seepage field was discussed. In the numerical tests, the influence of the permeability coefficients and water level rising rates on the seepage field and landslide stability was analyzed. The main findings are summarized as follows:

The landslide deformation was found to be associated with the pore water pressure variation during the reservoir filling using the grey relational analysis. In an area, when the pore water pressure started to rise, the deformation increased at the same time. Then, the deformation rate declined following the equilibrium of the pore water pressure. The main increasing stage of the landslide surface displacement was consistent with the general rising period of the pore water pressure inside the landslide. The increasing period of the pore water pressure within the landslide under reservoir filling was proposed to be a critical period, during which large landslide deformation occurred.

The mechanism for the landslide deformation and stability variation subjected to the reservoir filling was analyzed. The impounded reservoir provided the buttressing force acting on the landslide surface, which increased the landslide resistance and thus raised the landslide stability. However, the reservoir water infiltration caused the matric suction dissipation and pore water pressure increase within the landslide soil, which reduced the landslide shear strength and then reduced the landslide stability. The landslide stability subjected to the reservoir filling was governed by these two effects. When the former effect prevailed over the latter, the landslide stability increased and vice versa.

The landslide stability under different hydraulic conductivities and water level rising rates subjected to the reservoir filling was discussed. The buttressing effect of the reservoir enlarged gradually over the water level rising period. During 
this stage, less water flowed into the landslide under a higher water level rising rate or a lower permeability coefficient. Therefore, the buttressing effect of the reservoir was dominated, and thus, a greater FOS appeared. However, during the maintaining stage, the reservoir water flowed into the landslide continuously to cause the matric suction dissipation and pore water pressure increase, which reduced the landslide shear strength and then decreased the landslide stability.

\section{Data Availability}

The data used in this study are available from the corresponding author upon reasonable request.

\section{Conflicts of Interest}

The authors declare no conflicts of interest.

\section{Acknowledgments}

This study is funded by the Key Program of the National Natural Science Foundation of China (41630643), the National Key Research and Development Program of China (2017YFC1501302), and the Fundamental Research Funds for the Central Universities, China University of Geosciences (Wuhan) (CUGCJ1701).

\section{References}

[1] W. Yi, Z. P. Meng, and Q. L. Yi, Theory and Method of Landslide Stability Prediction in the Three Gorges Reservoir Area, Science Press, Beijing, 2011.

[2] Y. Zhang, X. Hu, D. D. Tannant, G. Zhang, and F. Tan, "Field monitoring and deformation characteristics of a landslide with piles in the Three Gorges Reservoir area," Landslides, vol. 15, no. 3, pp. 581-592, 2018.

[3] E. E. Alonso and N. M. Pinyol, "Numerical analysis of rapid drawdown: applications in real cases," Water Science and Engineering, vol. 9, no. 3, pp. 175-182, 2016.

[4] N. M. Pinyol, E. E. Alonso, J. Corominas, and J. Moya, "Canelles landslide: modelling rapid drawdown and fast potential sliding," Landslides, vol. 9, no. 1, pp. 33-51, 2012.

[5] M. M. Berilgen, "Investigation of stability of slopes under drawdown conditions," Computers and Geotechnics, vol. 34, no. 2, pp. 81-91, 2007.

[6] P. A. Lane and D. V. Griffiths, "Assessment of stability of slopes under drawdown conditions," Journal of Geotechnical and Geoenvironmental Engineering, vol. 126, no. 5, pp. 443-450, 2000.

[7] C. Viratjandr and R. L. Michalowski, "Limit analysis of submerged slopes subjected to water drawdown," Canadian Geotechnical Journal, vol. 43, no. 8, pp. 802-814, 2006.

[8] G. Sun, Y. Yang, W. Jiang, and H. Zheng, "Effects of an increase in reservoir drawdown rate on bank slope stability: a case study at the Three Gorges Reservoir, China," Engineering Geology, vol. 221, pp. 61-69, 2017.

[9] Q. Wu, H. Tang, X. Ma et al., "Identification of movement characteristics and causal factors of the Shuping landslide based on monitored displacements," Bulletin of Engineering
Geology and the Environment, vol. 78, no. 3, pp. 2093-2106, 2019.

[10] F. Tan, X. Hu, C. He et al., "Identifying the main control factors for different deformation stages of landslide," Geotechnical and Geological Engineering, vol. 36, no. 1, pp. 469-482, 2018.

[11] D. M. Gu, D. Huang, W. D. Yang, J. L. Zhu, and G. Y. Fu, "Understanding the triggering mechanism and possible kinematic evolution of a reactivated landslide in the Three Gorges Reservoir," Landslides, vol. 14, no. 6, pp. 2073-2087, 2017.

[12] M. Xia, G. M. Ren, S. S. Zhu, and X. L. Ma, "Relationship between landslide stability and reservoir water level variation," Bulletin of Engineering Geology and the Environment, vol. 74, no. 3, pp. 909-917, 2015.

[13] G. W. Jia, T. L. T. Zhan, Y. M. Chen, and D. G. Fredlund, "Performance of a large-scale slope model subjected to rising and lowering water levels," Engineering Geology, vol. 106, no. 1-2, pp. 92-103, 2009.

[14] X. Hu, M. Zhang, M. Sun, K. Huang, and Y. Song, "Deformation characteristics and failure mode of the Zhujiadian landslide in the Three Gorges Reservoir, China," Bulletin of Engineering Geology and the Environment, vol. 74, no. 1, pp. 1-12, 2015.

[15] L. Fan, G. Zhang, B. Li, and H. Tang, "Deformation and failure of the Xiaochatou landslide under rapid drawdown of the reservoir water level based on centrifuge tests," Bulletin of Engineering Geology and the Environment, vol. 76, no. 3, pp. 891-900, 2017.

[16] F. Wang, Y. Zhang, Z. Huo, X. Peng, S. Wang, and S. Yamasaki, "Mechanism for the rapid motion of the Qianjiangping landslide during reactivation by the first impoundment of the Three Gorges Dam reservoir, China," Landslides, vol. 5, no. 4, pp. 379-386, 2008.

[17] F. O. Jones, Landslides along the Columbia River Valley, Northeastern Washington (No. 367), US Government Printing Office, 1961.

[18] W. Riemer, "Landslides and reservoirs (keynote paper)," in Proceedings of the 6th International Symposium on Landslides, pp. 1373-2004, Christchurch, 1992.

[19] M. Rinaldi, N. Casagli, S. Dapporto, and A. Gargini, "Monitoring and modelling of pore water pressure changes and riverbank stability during flow events," Earth Surface Processes and Landforms, vol. 29, no. 2, pp. 237-254, 2004.

[20] X. Q. Luo, H. Sun, L. G. Tham, and S. M. Junaideen, "Landslide model test system and its application on the study of Shiliushubao landslide in Three Gorges Reservoir area," Soils and Foundations, vol. 50, no. 2, pp. 309-317, 2010.

[21] C. Zangerl, E. Eberhardt, and S. Perzlmaier, "Kinematic behaviour and velocity characteristics of a complex deep-seated crystalline rockslide system in relation to its interaction with a dam reservoir," Engineering Geology, vol. 112, no. 1-4, pp. 53-67, 2010.

[22] P. Paronuzzi, E. Rigo, and A. Bolla, "Influence of filling-drawdown cycles of the Vajont reservoir on Mt. Toc slope stability," Geomorphology, vol. 191, pp. 75-93, 2013.

[23] Z.-W. Zhu, B. Liu, P. Liu, B. Y. Zhao, and Z. Y. Feng, "Model experimental study of landslides based on combined optical fiber transducer and different types of boreholes," Catena, vol. 155, pp. 30-40, 2017. 
[24] J.-J. Wang, H. P. Zhang, L. Zhang, and Y. Liang, "Experimental study on heterogeneous slope responses to drawdown," Engineering Geology, vol. 147-148, pp. 52-56, 2012.

[25] T. D. Stark, N. H. Jafari, A. L. Leopold, and T. L. Brandon, "Soil compressibility in transient unsaturated seepage analyses," Canadian Geotechnical Journal, vol. 51, no. 8, pp. 858-868, 2014.

[26] F. Luo and G. Zhang, "Progressive failure behavior of cohesive soil slopes under water drawdown conditions," Environmental Earth Sciences, vol. 75, no. 11, 2016.

[27] S. Li, Q. Sun, Z. Zhang, and X. Luo, "Physical modelling and numerical analysis of slope instability subjected to reservoir impoundment of the Three Gorges," Environmental Earth Sciences, vol. 77, no. 4, 2018.

[28] H. Moriwaki, T. Inokuchi, T. Hattanji, K. Sassa, H. Ochiai, and G. Wang, "Failure processes in a full-scale landslide experiment using a rainfall simulator," Landslides, vol. 1, no. 4, pp. 277-288, 2004.

[29] H. Tang, X. Hu, C. Xu, C. Li, R. Yong, and L. Wang, "A novel approach for determining landslide pushing force based on landslide-pile interactions," Engineering Geology, vol. 182, pp. 15-24, 2014.

[30] Z. Zhang, T. Wang, S. Wu, H. Tang, and C. Liang, "Investigation of dormant landslides in earthquake conditions using a physical model," Landslides, vol. 14, no. 3, pp. 1181-1193, 2017.

[31] C. He, X. Hu, D. D. Tannant, F. Tan, Y. Zhang, and H. Zhang, "Response of a landslide to reservoir impoundment in model tests," Engineering Geology, vol. 247, pp. 84-93, 2018.

[32] S. Iai, "Similitude for shaking table tests on soil-structure-fluid model in 1g gravitational field," Soils and Foundations, vol. 29, no. 1, pp. 105-118, 1989.

[33] P. W. Bridgman, Dimensional Analysis, Yale University Press, 1922.

[34] Y. Zhang, H. Tang, C. Li et al., "Design and testing of a flexible inclinometer probe for model tests of landslide deep displacement measurement," Sensors, vol. 18, no. 2, p. 224, 2018.

[35] R. J. Renka, "Interpolation of data on the surface of a sphere," ACM Transactions on Mathematical Software, vol. 10, no. 4, pp. 417-436, 1984.

[36] F. Yuan, "Automatic drawing of equal quantity curve," Computer Aided Engineering, vol. 3, 1998.

[37] GEO-SLOPE International Ltd., Seepage and Stability Modeling with SEEP/W and SLOPE/W (Users Manuals), GEO-SLOPE International Ltd., Calgary, Canada, 2007.

[38] D. Y. Zhu, C. F. Lee, Q. H. Qian, and G. R. Chen, “A concise algorithm for computing the factor of safety using the Morgenstern-Price method," Canadian Geotechnical Journal, vol. 42, no. 1, pp. 272-278, 2005.

[39] M. T. Van Genuchten, "A closed-form equation for predicting the hydraulic conductivity of unsaturated soils 1," Soil Science Society of America Journal, vol. 44, no. 5, pp. 892-898, 1980.

[40] S. K. Vanapalli, D. G. Fredlund, D. E. Pufahl, and A. W. Clifton, "Model for the prediction of shear strength with respect to soil suction," Canadian Geotechnical Journal, vol. 33, no. 3, pp. 379-392, 1996. 

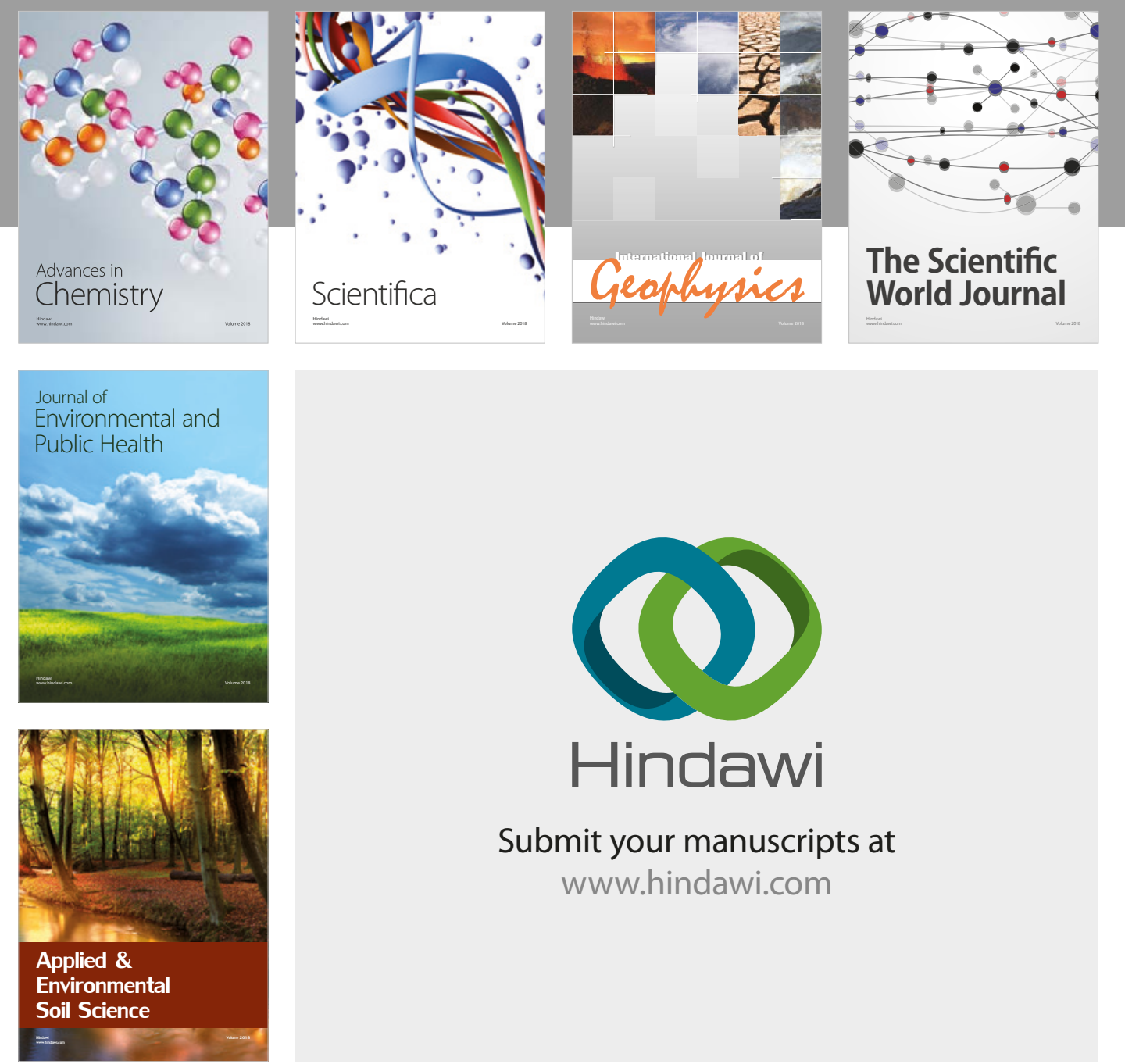

The Scientific

\section{World Journal}
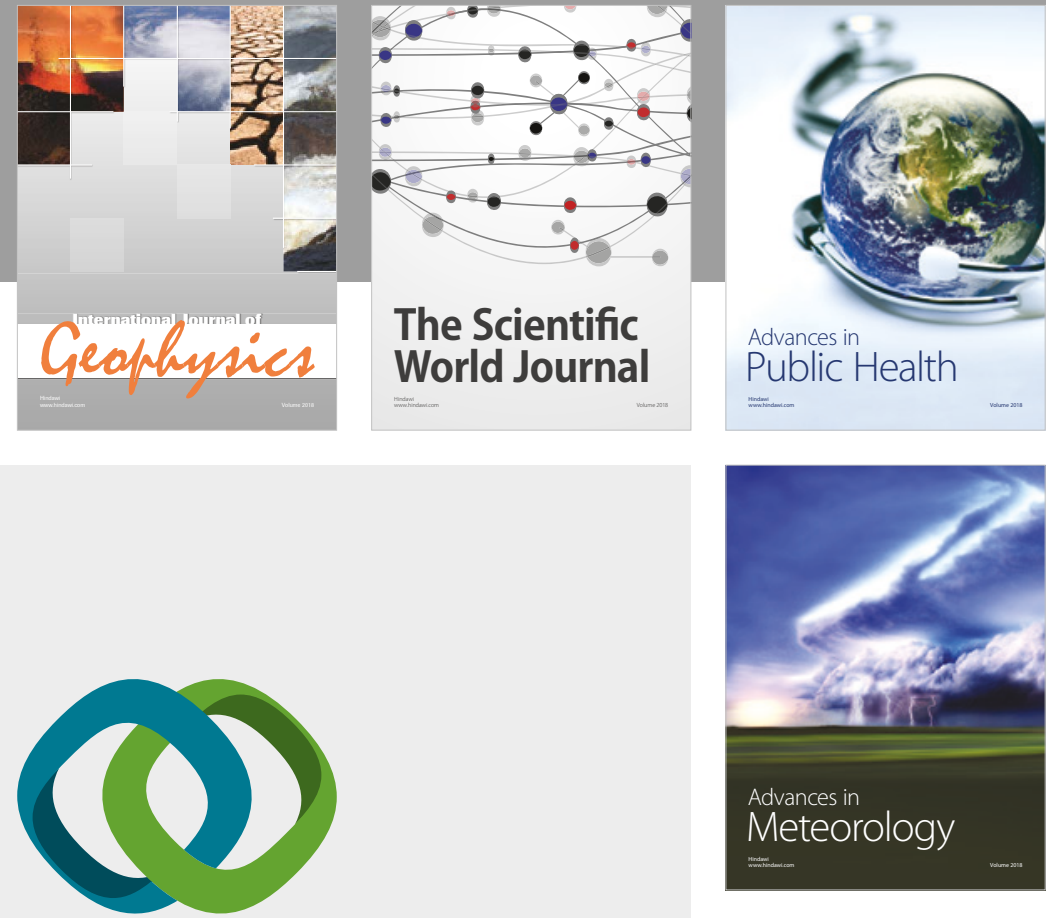

Advan

Public Health

\section{Hindawi}

Submit your manuscripts at

www.hindawi.com
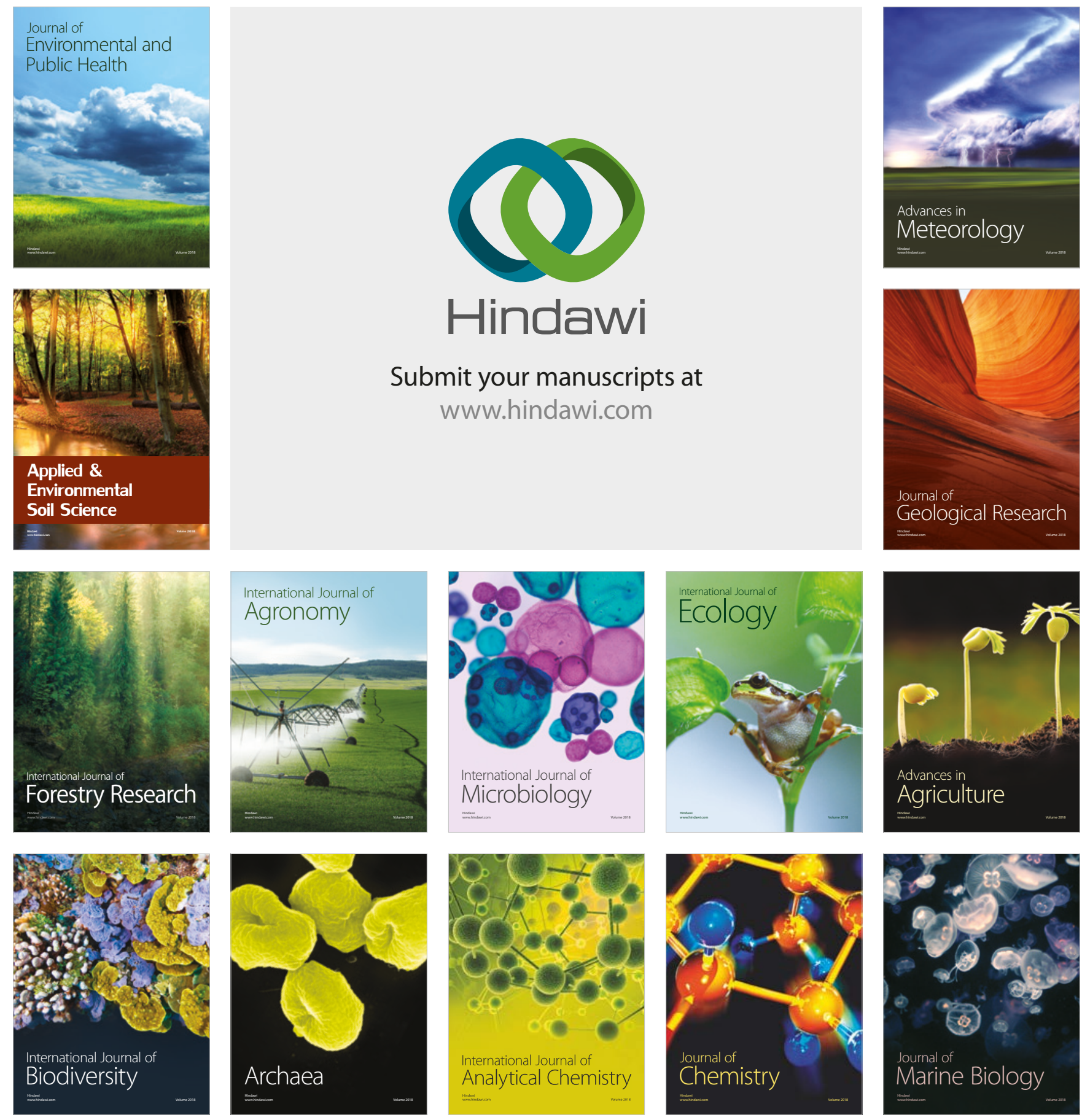